\title{
Gold Nanoparticles and Nanorods in Nuclear Medicine: A Mini Review
}

\author{
Daria Maccora ${ }^{1,2} \mathbb{D}^{\circ}$, Valentina Dini ${ }^{3,4, *}$, Chiara Battocchio ${ }^{5}(0)$, Ilaria Fratoddi ${ }^{6}(0)$ \\ Antonella Cartoni ${ }^{6}$, Dante Rotili ${ }^{7}$, Massimo Castagnola ${ }^{8}$, Riccardo Faccini ${ }^{4,9}$, Isabella Bruno ${ }^{1}$ (D), \\ Teresa Scotognella ${ }^{1}$ (D) Alessandro Giordano ${ }^{1,2, *}$ and Iole Venditti ${ }^{5, *}$ (D) \\ 1 Nuclear Medicine Unit, Fondazione Policlinico Universitario A. Gemelli IRCCS, 00168 Rome, Italy \\ 2 Institute of Nuclear Medicine, Università Cattolica del Sacro Cuore, 00168 Rome, Italy \\ 3 National Center for Innovative Technologies in Public Health, Istituto Superiore di Sanità, 00161 Rome, Italy \\ INFN, Sezione di Roma1, 00185 Rome, Italy \\ Sciences Department Roma Tre University of Rome, 00146 Rome, Italy \\ Chemistry Department, Sapienza University of Rome, 00185 Rome, Italy \\ Department of Chemistry and Pharmaceutical Technologies, Sapienza University of Rome, 00185 Rome, Italy \\ Laboratory of Proteomics-IRCCS-Fondazione Santa Lucia, 00143 Rome, Italy \\ 9 Physic Department, Sapienza University of Rome, 00185 Rome, Italy \\ * Correspondence: valentina.dini@iss.it (V.D.); alessandro.giordano@unicatt.it (A.G.); \\ iole.venditti@uniroma3.it (I.V.); Tel.: +39-06-49902719 (V.D.); +39-06-30154978 (A.G.); +39-06-5733-3388 (I.V.)
}

Received: 20 July 2019; Accepted: 6 August 2019; Published: 8 August 2019

check for

\begin{abstract}
In the last decade, many innovative nanodrugs have been developed, as well as many nanoradiocompounds that show amazing features in nuclear imaging and/or radiometabolic therapy. Their potential uses offer a wide range of possibilities. It can be possible to develop nondimensional systems of existing radiopharmaceuticals or build engineered systems that combine a nanoparticle with the radiopharmaceutical, a tracer, and a target molecule, and still develop selective nanodetection systems. This review focuses on recent advances regarding the use of gold nanoparticles and nanorods in nuclear medicine. The up-to-date advancements will be shown concerning preparations with special attention on the dimensions and functionalizations that are most used to attain an enhanced performance of gold engineered nanomaterials. Many ideas are offered regarding recent in vitro and in vivo studies. Finally, the recent clinical trials and applications are discussed.
\end{abstract}

Keywords: gold nanoparticles; gold nanorods; nanoradiocompounds; radiopharmaceuticals; drug delivery; theragnostic; nuclear medicine; nanomedicine

\section{Introduction}

In the last decade, there has been a great increase in nanotechnology research, producing numerous publications and innovative products in several fields such as energy, catalysis, optoelectronics, sensing, and biotechnology [1-28]. Nanomaterials are proposed in medicine to increase the efficiency of therapies and diagnosis. In fact, in the diagnostic field, nanomaterials potentially introduce noteworthy advantages with respect to the traditional use of single molecules as radioactive tracers for in vivo and in vitro imaging [29-32]. Moreover, in therapy, nanodrug preparations are more useful than the usual low-molecular-weight drugs in many features. They protect the drugs, reducing renal elimination and hepatic degradation, leading to extended circulation time. Furthermore, nanoformulations increase drug concentrations at the pathological target, thereby improving the balance between the efficacy and the toxicity of systemic chemotherapeutic interventions. 
Radiopharmaceuticals are showing amazing outcomes in diagnostic $(90 \%)$ and therapeutic (10\%) applications for many diseases such as cancer, heart and brain diseases, and so on [33]. They consist of a radioactive nuclide linked to a biologically active molecule directed to the target of interest. When radionuclides emit $\gamma$ rays (either directly, as pure $\gamma$ emitters, or indirectly, as $\beta+$ emitters), the radiopharmaceutical is intended for diagnostic imaging. When radionuclides emit $\beta-$ or $\alpha$ particles (thanks to the cell-damaging properties) the radiopharmaceutical is used for therapeutic applications and, in some recent research studies, even for radio-guided surgery [34-36]. Theragnostics is a new term that implies the use of the same molecule, labeled with different radionuclides, for both diagnostic and therapeutic purposes [37-39].

Radiopharmaceuticals have been increasingly used for medical diagnosis since the late 1940s, when nuclear medicine was born. Nuclear medicine aims at evaluating both physiological function as well as biochemical changes in disease conditions; it includes two-dimensional (2D) imaging (planar scintigraphy) and three-dimensional (3D) imaging (single-photon emission computed tomography, SPECT, and positron emission tomography, PET). The functional information obtained by SPECT and PET may need to be coupled with the anatomic/morphologic information typically provided by computed tomography (CT) (hence SPECT and PET are now commonly called SPECT-CT and PET-CT): these approaches, named "hybrid imaging", have many advantages as well as high sensitivity, good spatial resolution, and the possibility to correctly locate functional abnormalities (by the SPECT or PET component) within a definite anatomic field (by the CT component) [34].

The $\gamma$-emitting radionuclides that are used for planar and SPECT imaging are usually obtained within hospital nuclear medicine facilities (or research departments) from small portable generators; some are produced by nuclear reactors and then shipped to the hospital facility ready to use. The $\beta+$ emitting radionuclides that are used for PET imaging are sometimes obtained from generators—or, more frequently, from cyclotrons located in industrial sites or in hospitals. PET radionuclides contribute to the higher costs of PET and PET-CT imaging as compared to planar, SPECT, and SPECT-CT imaging.

The B-emitting radionuclides deliver highly energetic electrons that release their energy over up to 1 or 2 millimeters (path length) in the adjacent tissues; therefore, they are commonly used for therapeutic purposes (usually called radiometabolic therapy) [40,41]. Over the past 40 years, the therapeutic potential of several other radionuclides emitting $\alpha$ particles or Auger electrons has been assessed. $\alpha$ particle-emitting radionuclides are of considerable interest for radionuclide therapy because of their high cytotoxicity and very short path length. The most common use of radiometabolic therapy is the treatment of thyroid-related diseases [42,43]. Some other radionuclides emitting $\beta$-particles are also used in radiotherapy departments for the low-dose rate "brachytherapy" of some tumors, particularly prostate cancer [44-46].

Knowing this panorama, we can certainly say that the traditional health care and medical technology might be deeply influenced by the application of nanotechnology to nuclear medicine principles. A great impact on functional diagnosis and radiometabolic treatment can be expected, although the clinical applications are still at an initial phase. In fact, many nanoproducts have been developed, and the Food and Drug Administration (FDA) is receiving many requests for the approval of nanomaterials conjugated with approved drug and radioactive agents [47].

Nanoradiopharmaceuticals show excellent promise in nuclear imaging and/or radiometabolic therapy. Their potentials offer more possibilities. It can be possible to develop nondimensional systems of existing radiopharmaceuticals or build engineered systems that combine a nanoparticle with the radiopharmaceutical, a tracer, and a target molecule and still develop selective nanodetection systems.

Among others, a main advantage of nanosized radioactive formulations is the presence of numerous radioactive atoms within a single nanoparticle. The conventional methods will allow only one tumor-avid biomolecule to carry one radioactive nuclide, but effective tumor therapy requires maximum radioactivity (effective payload) within the tumor site. The nanoparticles conjugated to tumor-avid biomolecules will be used as a Trojan horse to introduce a higher ratio of radioactive 
particles into the tumor. Thus, nanoparticles will become optimized drug delivery systems over a wide range of diseases, especially in cancer.

Nanoparticles can usually be accumulated in tumor endothelial cells but in nonspecific ways, such as passive targeting by means of the enhanced permeability and retention (EPR) effect. The finding of the EPR effect is one of the greatest advances leading to the development of targeted antitumor therapy. In addition to the enhanced leakiness of tumorous vessels, the EPR effect is also because solid tumors have a tendency to lack functional lymphatics, limiting in that way the removal of extravasated nanomaterials from the target site. Unluckily, when we are in the presence of large tumors, the local drug delivery is impracticable, because in these cases, the tumors have poor vascularization. In the passive targeting, the drug's achievement is directly correlated to the circulation time. The nanoparticles' functionalization can also afford a stealth surface that would moderate the reticuloendothelial system (RES) recognition of NPs and extend the circulation half-life. RES consists of cells descending from the monocytes, which can achieve the phagocytosis of foreign compounds. It is well-known that $90 \%$ of the RES are in the liver. Even though the EPR effect affords the opportunity for targeting into the tumor, it is not applicable to low-vascular permeability cancers. In addition, passive targeting could be not enough for drug accumulation in tumors. Where EPR is weak, NPs should be willing to aid permeation beyond the vasculature and into the tumor environment. While dissimilar passive targeting demonstrates low tumor selectivity, active targeting produces a higher intratumoral accumulation of a nanocarrier and drug. Consequently, it is positive to develop active targeting systems that can selectively identify specific cells or tissues, attaching specific ligands such as antibodies, aptamers, peptides, and so forth, on nanocarrier surfaces [48,49].

Among others, the gold-based nanomaterials have amazing features that make them very suitable and valuable in nanomedicine. In fact, they show remarkable chemical-physical properties, such as an easy modifiable morphology/size/surface, modulable optical absorption and scattering, photothermal and photoacoustic enhancements, and a wide surface/volume ratio that is suitable for interaction with the environment [50-53]. The gold surface can be functionalized and linked with drugs [54-57] and biomolecules, such as enzymes, antibodies, DNA, and peptides to achieve a specific site [58-66], and they are also studied to develop innovative antibacterial systems [67-70].

In the wide field of advanced materials that represent the frontier where gold-based materials and nuclear medicine meet, this review provides an updated scenario of the progress in this young research field, focusing on gold nanoparticles (AuNPs) and nanorods (AuNRs) used in diagnosis and therapy, as schematized in Figure 1. The first key topic is the chemical preparation of gold-based nanomaterials, which is focused on spheres and rods. The importance of the shape, size, and surface functionalization of these materials in nuclear medicine applications will be highlighted. Then, a review of the most recent in vitro and in vivo studies is presented as a preliminary test for clinical application. Finally, the recent clinical trials and applications are discussed. 


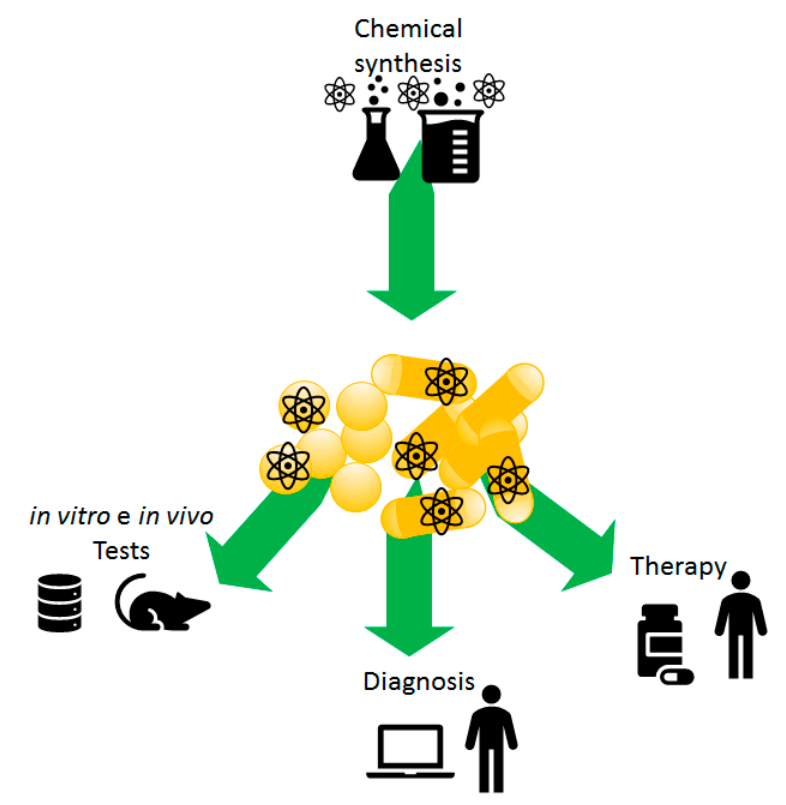

Figure 1. Key aspects of gold nanoparticles (AuNPs) and gold nanorods (AuNRs) in nuclear medicine.

\section{Gold Nanoparticle and Nanorods: Preparations and Features}

The peculiar chemical-physical features presented by gold-based nanomaterials make them an excellent platform in nanomedicine, especially in the case of AuNPs and AuNRs [71,72]. As it is well-known, these materials show a large surface to volume ratio that increases the interaction with the surrounding biochemical medium. They are easy synthesized and functionalized by chemical routes. The Turkevich process [73] produces highly stable AuNPs with dimensions in the range of 20 to $50 \mathrm{~nm}$, wherein the capping agent is citrate, giving a net negative superficial charge that prevents particle aggregation. The Schiffrin-Brust method [74] is the most used synthetic route, which is always based on the reduction in two phases of $\mathrm{Au}^{3+}$ using different capping agents and reduction agents. Alongside these well-known approaches, the seed-mediated growth and use of bacteria are the other usual preparation methods to obtain gold-based nanomaterials, which are inert and stable [75,76].

Further, gold-based nanomaterials possess local surface plasmonic resonance (LSPR), which can be modulated by variations in shape, dimension, and aggregate formation $[59,77,78]$. The size and shape of particles modify the local electron confinement, which produces a variation in the LSPR absorption maxima. These properties endure evident changes when an anisotropic system is proposed, such as in the synthesis of nanorods instead of nanoparticles. AuNRs present strong plasmon resonance absorption, with both transversal and longitudinal LSPR peaks in two different spectrum ranges: the first in the visible range, and the second in the infrared (IR) region of electromagnetic radiation.

The use of AuNPs and AuNRs often requires specific functionalization wherein they are conjugated with a target-specific ligand. The ligand molecule was anchored with a gold surface but preserved a free ending functional group, which was able to form successive bond. Essentially, there are three ways for the introduction of targeted ligands on a gold surface. (i) First, there is physical adsorption, which occurs by means of electrostatic or hydrophobic interaction. It is a rapid process and avoids the need for a complex synthesis process. Nevertheless, any modification in experimental parameters $(\mathrm{pH}$, ionic strength etc.) produces a detachment of the ligand molecule. (ii) Second, there is a covalent bond that in general is based on the strong bonding interaction between the gold surface and $\mathrm{S}$ or $\mathrm{N}$ atoms (alkanethiolates, alkaneamines glutathione, cysteine, xanthates, anthocyanins, disulfide, thioethers, aminoethers, dithiocarbamate). (iii) Lastly, there is an explicit tag with specific ligand molecules to obtain the desired target.

AuNPs and AuNRs are easily conjugated with radionuclides for diagnostic or therapeutic purposes. In Table 1, examples of AuNPs and AuNRs are reported together with: (i) the dimension and 
(ii) surface functionalization of gold-based nanomaterials before the radionuclides conjugation, (iii) the conjugated radionuclide, (iv) the application in nuclear medicine, and (v) the reference to recent literature. All of this is presented with the aim of providing readers with a useful guide for orientation in this sector.

In several of these cases, the gold surface functionalization was realized by polyethylene glycol (PEG) coating and showed increased therapeutic efficacy of the formulation for radiosensitization. In fact, PEG covering reduces the AuNPs recognition by RES and protracts the circulation half-life. The RES involves cells descending from the monocytes, which are able to perform the phagocytosis of extraneous materials and particles [79]. The following paragraphs will illustrate the possibilities and advantages of using AuNPs and AuNRs in biotechnological applications, focusing on the field of nuclear medicine.

Table 1. Functionalized AuNPs and AuNRs reported with the conjugated radionuclide and the application in Nuclear Medicine. PET: positron emission tomography, SPECT: single-photon emission computed tomography.

\begin{tabular}{|c|c|c|c|c|c|}
\hline Morphology & $\begin{array}{l}\text { Gold Surface } \\
\text { Functionality }\end{array}$ & Size (nm) & Radionuclides & $\begin{array}{l}\text { Nuclear Medicine } \\
\text { Applications }\end{array}$ & Ref. \\
\hline \multicolumn{6}{|c|}{ AuNPs } \\
\hline & PEI & 3 & ${ }^{99} \mathrm{Tc}$ & SPECT/TC & [80] \\
\hline & Tannic acid & 40 & ${ }^{124} \mathrm{I}$ & PET & [30] \\
\hline & PEG & 30 & ${ }^{198} \mathrm{Au}$ & SPECT & [81] \\
\hline & PEG & 15 & ${ }^{211} \mathrm{At}$ & cytotoxicity & [82] \\
\hline & PEG & 30 & ${ }^{177} \mathrm{Lu}$ & brachytherapy & [44] \\
\hline & Amino-PEG & 30 & ${ }^{99} \mathrm{Tc}$ & SPECT/CT & [83] \\
\hline & PEG & 5 & ${ }^{199} \mathrm{Au}$ & SPECT, biodistribution & [84] \\
\hline & PEI & 3 & ${ }^{99} \mathrm{Tc}$ & SPECT/TC & [85] \\
\hline & PEG & 30 & ${ }^{177} \mathrm{Lu}$ & $\begin{array}{l}\text { treatment of breast } \\
\text { cancer }\end{array}$ & [86] \\
\hline & thiol mannose & 20 & ${ }^{99} \mathrm{Tc}$ & $\begin{array}{l}\text { sentinel lymph node } \\
\text { detection }\end{array}$ & [87] \\
\hline & allylamine & 5 & ${ }^{89} \mathrm{Zr}$ & PET, biodistribution & [88] \\
\hline & $\mathrm{PEG}^{*}$ & 10 & ${ }^{18} \mathrm{~F}$ & PET & [89] \\
\hline \multicolumn{6}{|c|}{ AuNRs } \\
\hline $\mathbf{s}$ & PEG & $20-60$ & ${ }^{169} \mathrm{Yb}$ & brachytherapy & [90] \\
\hline & PEG & $25-90$ & ${ }^{131} \mathrm{I}$ & biodistribution & [91] \\
\hline & PEG & $20-90$ & ${ }^{125} \mathrm{I}$ & bioactivity & [92] \\
\hline & polydopamine & $15-60$ & ${ }^{125} \mathrm{I}$ & SPECT/TC & [93] \\
\hline & PEG & $15-50 ; 15-75$ & ${ }^{64} \mathrm{Cu}$ & PET, biodistribution & [41] \\
\hline & HPMA ** & - & ${ }^{90} \mathrm{Y}$ & $\begin{array}{l}\text { treatment of prostate } \\
\text { tumors }\end{array}$ & [94] \\
\hline & PEG & $10-40$ & ${ }^{198} \mathrm{Au}$ & SPECT, biodistribution & [81] \\
\hline & PEG & $10-25$ & ${ }^{131} \mathrm{I}$ & biodistribution & [95] \\
\hline & PEG & $10-50$ & ${ }^{125} \mathrm{I}$ & biodistribution & [96] \\
\hline & PEG & - & ${ }^{125} \mathrm{I}$ & SPECT, PET & [97] \\
\hline
\end{tabular}

* PEG = polyethylene glycol, ${ }^{* *}$ HPMA = N-(2-hydroxypropyl)methacrylamide.

\section{1. $A u N P S$}

AuNPs can be synthesized by means of several processes such as chemical, physical, and biological methods $[24,49-51,65]$. A well-known bottom-up approach is a wet reduction in the presence of a capping agent $[55,57,59-62,64]$. The obtained AuNPs can be easily investigated by microscope techniques, such as transmission electron microscope (TEM), scanning electron microscope (SEM), and atomic force microscope (AFM) [98-102]. Capped AuNPs are prepared by using a water solution of tetrachloroauric acid as the gold precursor, a ligand molecule, and a reducing agent. 
Functionalizations can be produced on the gold surface using different synthetic strategies: (i) the method of ligand exchange; (ii) the introduction of bifunctional thiols; (iii) the use of many different capping agents throughout the synthesis mixture; and (iv) the derivation reaction in a post-synthesis procedure [99,103-106]. The ligand exchange is an easy and cheap mode to functionalize the gold surface, but frequently leads to a partial coverage that is short lasting and stable in time. In fact, this approach is based on an equilibrium reaction associated with the Nernst distribution [99]. The use of bifunctional thiols (HS-X), which presents a free end group X, such as thiol, acid, amine, ester, and ether, allows the particle interactions with the external environment and enhance post-synthesis modifications. It is also possible to introduce different capping agents at the same time: in this way, many superficial functionalities can be introduced, but this approach needs strict control of the synthetic parameters $(\mathrm{pH}$, concentrations, reducing agent, temperature) to assurance good reproducibility and dispersity $[107,108]$. The monodispersity is a key feature for the noble metal nanoparticles, which can be obtained by fine tuning experimental parameters during synthesis or by separation after synthesis [108-110].

The post-synthesis functionalization allows modifying the surface of the already purified and monodispersed nanoparticles. In this way, new features or new molecules or drugs are introduced on the particle ligands. The post-synthesis modification of the nanoparticles surface can be obtained through four main approaches, as schematized in Figure 2: (i) covalent attachment; (ii) electrostatic interaction; (iii) direct thiol reaction; and (iv) secondary interaction [111].

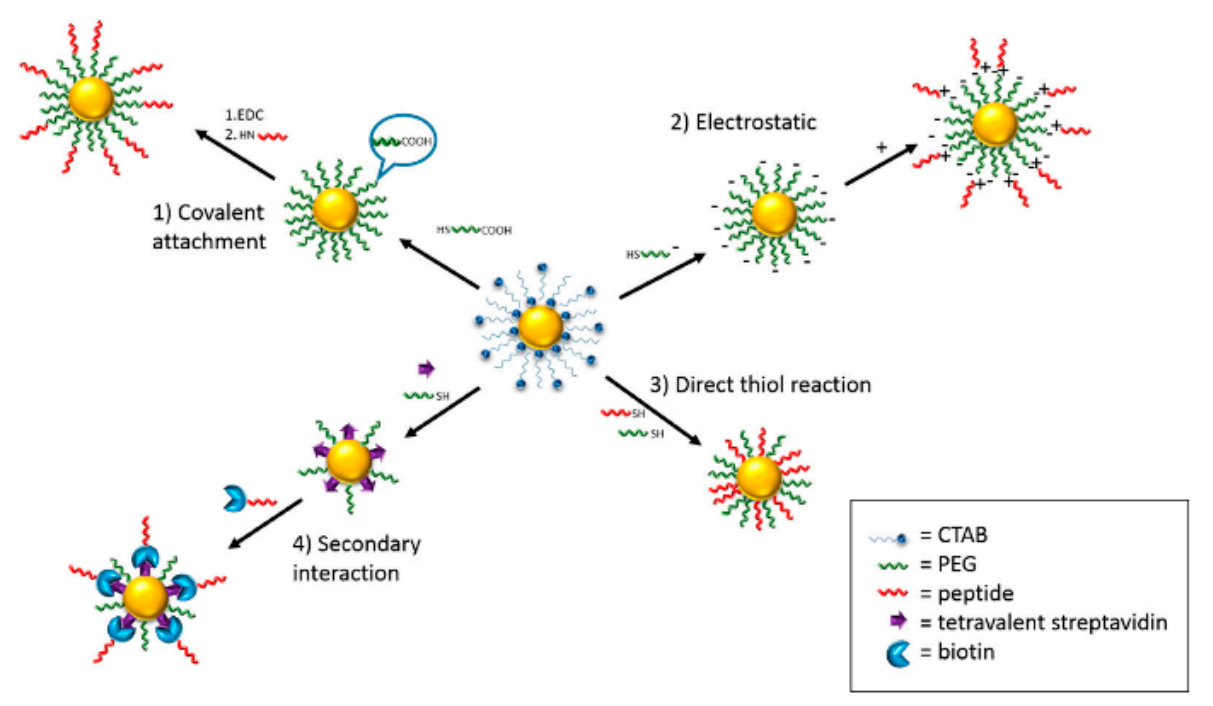

Figure 2. The four major surface modification approaches for the functionalization of nanoparticles, using PEG and a peptide as an example of a biomolecule. (1) Covalent attachment: covalent reactions such as EDC/NHS coupling occur between the PEG layer and biomolecule end groups. (2) Electrostatic: use cationic/anionic PEG and biomolecules to allow charge-charge conjugation. (3) Direct thiol reaction: both PEG and biomolecules loaded through thiol binding to the surface. (4) Secondary interaction: ligands are loaded onto the surface followed by the biomolecules containing a specific receptor to allow a ligand-receptor specific conjugation. Reproduced with permission from [111].

All of these approaches can be used to link radionuclides or their derivatives on AuNPs, but in many systems, the secondary interaction was preferred. For example, many AuNPs-PEG systems were studied as contrast agents for CT imaging. These systems exhibited several advantages compared with the clinical iodine-based contrast agents, such as better imaging performance and biocompatibility, longer blood circulation time, and manageable behaviors. Moreover, several ${ }^{99}$ Tc-labelled PEG-AuNPs have been developed as radiopharmaceuticals for SPECT imaging applications in cancer, sentinel lymph node (SLN), and other biological systems. In fact, ${ }^{99 \mathrm{~m}} \mathrm{Tc}$ 
is a perfect radioisotope for SPECT imaging due to its favorable low energy $\gamma$-ray (140 keV), suitable half-life $(6.02 \mathrm{~h})$, low cost, and commercial availability [80,83,85].

Recently, Kim et al. has developed AuNPs-PEG functionalized with tumor-targeting moieties and chemotherapeutic agents, combining CT and chemotherapy for the treatment of prostate cancer. The surfaces of AuNPs were functionalized with the prostate-specific membrane antigen (PSMA) aptamer. Furthermore, PSMA aptamer-conjugated AuNPs were able to effectively bring DOX to LNCaP cells and produce important cytotoxicity in those in vitro cells. Multifunctional AuNPs are suitable platforms for combining CT and targeted chemotherapy [112].

\subsection{AuNRs}

The chemical synthesis is a strong tool for the bottom-up approach in gold-based materials preparations $[49,63]$. In particular for AuNRs, by the strict control of chemical procedures, it can be possible to control dimensions and monodispersity, as reported in Figure 3. Park et al. performed detailed studies on the growth mechanism of AuNRs and the role of seed growth [113]. They proposed changing in classic seed-mediated synthesis via the time-based control of seed and reactant concentration increasing the production of AuNRs more than 100 times with respect to the conventional concentration, while keeping autonomous control and narrow distribution of the nanoparticle dimensions, aspect ratio, and volume. In this way, they are confident that they cost-effectively meet the increased demand for large quantities of AuNRs in emergent applications.

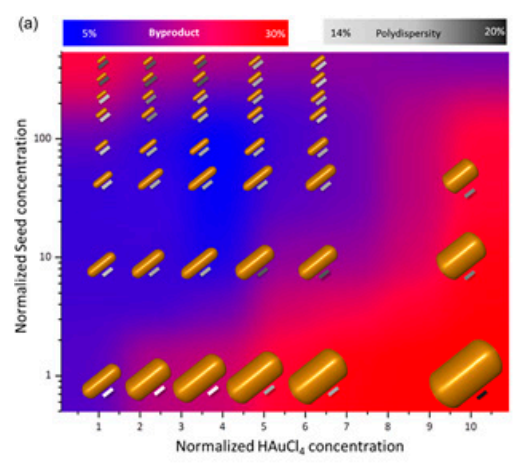

(c)
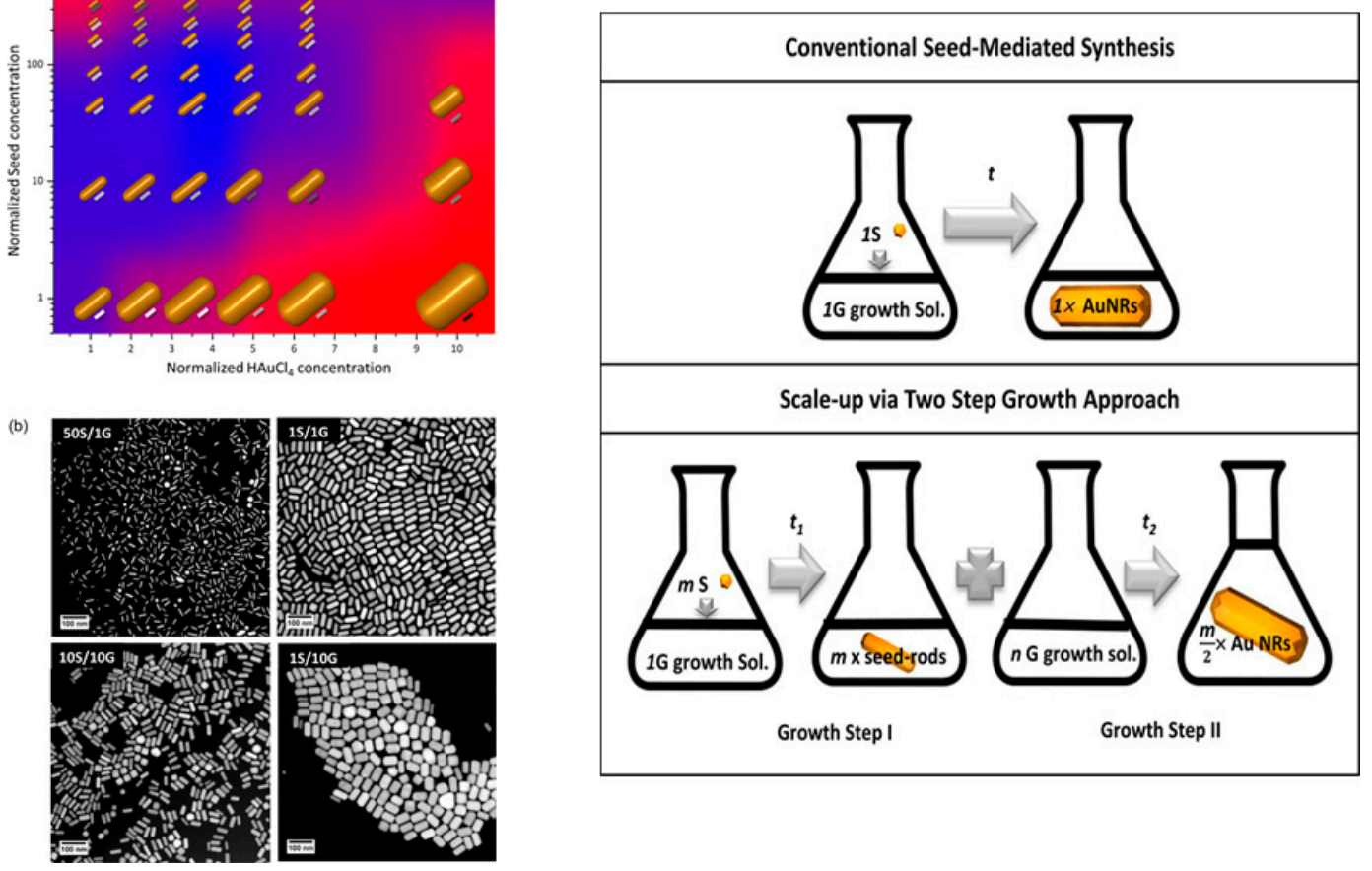

Figure 3. (a) Different AuNRs volume in function of seed concentration; (b) AuNRs TEM images, scale bars $100 \mathrm{~nm}$; (c) Comparing the conventional seed-mediated protocol and the two steps approach. Adapted from [113] with permission from the American Chemical Society (2017).

Moreover, AuNRs present amazing optical properties, such as two characteristic transverse and longitudinal surface plasmonic bands: the first in the visible $(\sim 520 \mathrm{~nm})$ range, and the second in the near-infrared $(\sim 900 \mathrm{~nm})$ region. This optical property is perfect for in vivo imaging and therapy, because the near-infrared region allows the maximum penetration of light into tissues. Additionally, the AuNRs surface chemistry allows multiple functionalization by various pharmaceutical agents. Capping molecules, such as cetyltrimethylammonium bromide (CTAB), can be replaced or conjugated 
with many molecules. PEG-modified AuNRs show a nearly neutral surface and have little in vivo cytotoxicity. The application of AuNRs in nuclear medicine has attracted great interest in the last few years $[91,95,114]$.

PEG-modified AuNRs were radiolabeled with ${ }^{131} \mathrm{I}$, and their in vivo biodistribution was investigated by intravenous injection into the rats [95]. Moreover, the in vivo stability and biological metabolism of the radiolabeled AuNRs in the rat's body were studied using a $\gamma$-camera. The obtained results showed the prominent uptake of ${ }^{131}$ I-PEG-AuNRs in the blood after intravenous administration, which showed that the ${ }^{131}$ I-PEG-AuNRs as whole particles are hardly sequestered on the gland-type organs. One of the reasons for the high blood retention of ${ }^{131}$ I-PEG-AuNRs was AuNRs surface modification with PEG, which postponed the uptake of radio conjugates by the RES and influenced the biodistribution profile and the clearance kinetics. The PEG-coated AuNRs persisted in the blood for long time, but the accumulation in liver and spleen decreased drastically. This protocol revealed that ${ }^{131}$ I-PEG-AuNRs are extraordinary stable in vivo condition. In a recent work, cyclic arginine-glycine-aspartate acid (RGD)-conjugated gold nanoparticles were used to follow integrins in high resolution by means of cryo-electron tomography: it is possible to localize AuNPs in cells and identify the precise interactors within cells $[115,116]$. This development is a clear example of the AuNPs use of structural cell biology.

Zhang et al. conjugated ${ }^{131}$ I-labeled AuNRs with cyclic arginine-glycine-aspartic acid (RGD) and investigated its biological characteristics for the targeted imaging of integrin $\alpha_{V} \beta_{3}$-expressing tumors [91]. The ${ }^{131}$ I-labeled AuNRs-PEG-CRGD probe targeted selectively and could be taken up by tumor cells mainly via integrin $\alpha$-receptor-mediated endocytosis. In vivo imaging, biodistribution, and autoradiography studies showed tumor uptake in integrin $\alpha_{V} \beta_{3}$-expressing tumors. For better investigation of inflammation, Shao et al. designed inflammation targeting nuclear and optical dual-modality contrast agents prepared by the ${ }^{125}$ I radiolabeling of AuNRs conjugated with anti-intercellular adhesion molecule 1 (ICAM-1) Ab [91]. The success of the targeted delivery of AuNRs inflammatory tissue enabled both nuclear and optical imaging of inflammation at the molecular or cellular level.

\section{In Vitro Evaluation of Radionuclides Delivered by AuNPs and AuNRs}

Studies in vitro are very important, because they improve knowledge of what happens at the molecular level when nanoparticles interact with biological systems (i.e., bloodstream, culture medium, and/or cell cytoplasm). Exploring these interactions is essential to understand the next biological processes such as distribution, metabolism, and elimination, etc., in vivo studies. Moreover, the in vitro evaluation of AuNPs and AuNRs presents different advantages such as lower cost, faster speed, and a lack of ethical concerns.

The in vitro studies evaluate different properties relative to nanoparticles, such as the toxicity, the uptake into the cells, their stability in biological solutions in relation to size and shape, and particle-coating dose $[117,118]$. In particular, the attachment of radionuclides could influence the surface properties and modify the capability of loading other targeting or therapeutic compounds. In the U87MG glioma cell line, the targeting capability of the arginine-glycine-aspartic acid (RGD) peptide after ${ }^{64} \mathrm{Cu}$ integration in AuNRs was assessed. The RGD maintains its capability of targeting integrin after ${ }^{64} \mathrm{Cu}$ treatment [41]. Similarly, the attachment of PEG-trastuzumab (HER2-specific monoclonal antibody molecules) on the AuNPs surface $(\varnothing=5 \mathrm{~nm})$ does not change the ${ }^{211}$ At absorption [82]. By contrast, the surfactant stabilizer CTAB, which is essential for the synthesis of AuNRs, exhibits strong cytotoxicity in terms of apoptosis and autophagy, and damage mitochondria producing intracellular reactive oxygen species (ROS) [119].

Of all the aforementioned properties, toxicity is the most studied. It can be defined as beneficial when radio gold-based nanomaterials are used for therapeutic treatments, or as detrimental when they are used for diagnostic procedures. The main endpoints studied to assess the toxicity in vitro are: (i) proliferation (i.e., MTT cell viability assay, clonogenic assay), (ii) apoptosis (i.e., annexin-V assay, 
Comet assay, TUNEL assay), (iii) membrane integrity (i.e., uptake of Trypan Blue (TB) or Neutral Red (NR) dyes), (iv) oxidative assays (i.e., evaluation of the content of reactive oxygen species), and (v) DNA damage [120,121].

Cytotoxicity at different concentrations of the ${ }^{198} \mathrm{AuNPs}$ with dimension ranged from 25 to $30 \mathrm{~nm}$ and encapsulated in arabinoxylan (AX) was determined in HeLa cells by NR dyes. The results show their non-toxic effect because they do not act on the cell viability and morphology (see Figure $4 a, b$ ). Consequently, the ${ }^{198}$ AuNPs encapsulated into AX could be employed for in vivo studies in the field of diagnostics [122].

A)

B)
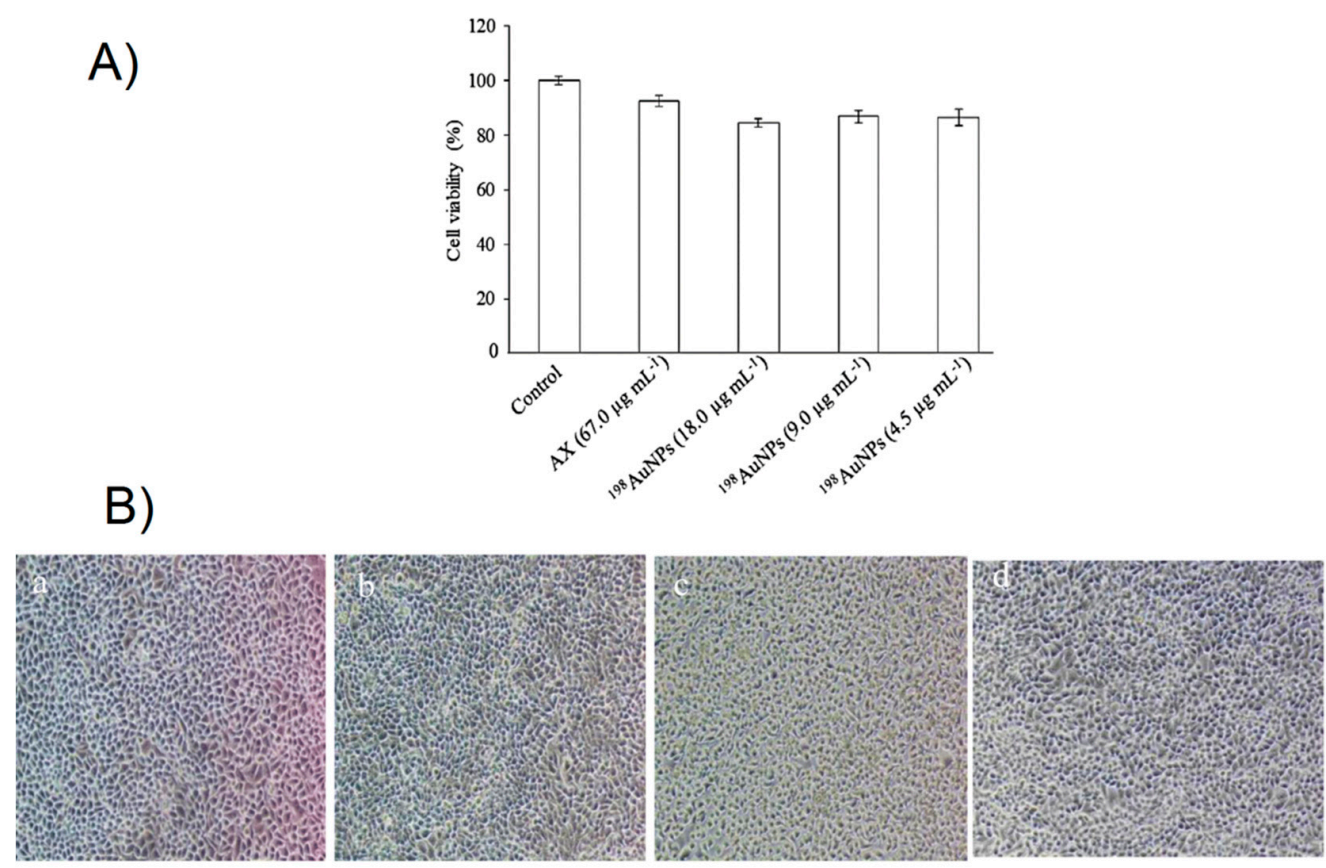

Figure 4. (A) Histogram showing percentage of cell viability against the HeLa cell line after incubation with arabinoxylan (AX) suspension. (B) Microscopic images showing no morphological changes (a) control cells, (b) AX-treated cells, (c) AX-encapsulated ${ }^{198}$ AuNP-treated cells, and (d) ${ }^{198}$ AuNP-treated cells. Adapted with permission from [122].

The cytotoxicity of the ${ }^{124} \mathrm{I}$-AuNPs embedded into dendritic cells (DCs) used for immunotherapy has been evaluated in terms of proliferation by MTT cell viability assay and in terms of apoptosis by annexin- $\mathrm{V}$ assay. The cell viability test has shown no significant differences between the labeled and unlabeled DCs in the range of concentrations studied (1.0 to $4.0 \mathrm{nM}$ ) over $48 \mathrm{~h}$. Moreover, ${ }^{124} \mathrm{I}$-AuNP uptake in the DCs did not altered their migration and their antigen uptake capacities. Overall, these results point toward the use of these AuNPs as platforms for nuclear and optical imaging applications [123].

Furthermore, the cytotoxicity in terms of viability of ${ }^{198} \mathrm{AuNPs}(\varnothing=3.7 \pm 1.0 \mathrm{~nm})$ integrated within the Lactobacillus bacteria cells (LACT) has been studied. The study was performed by using MTT test on breast cancer (MCF-7) and on normal colon (CRLA1790) cells, which were incubated with radioactive or non-radioactive LACT-AuNP. The results have shown in both cell lines a decrease of cell viability after incubation with LACT- ${ }^{198} \mathrm{AuNP}$ with the MCF-7 cells more radiosensitive than the CRLA1790 cells. Moreover, after incubation with non-radioactive LACT-AuNP, no cytotoxicity was observed in both cell lines [124]. Similar results are obtained embedded ${ }^{124}$ I-Au@AuCBs in the macrophage, which is used as a delivery system for photothermal therapy (PTT) in colon cancer cells (CT26) (see Figure 5) [125].

The cytotoxicity of PEG-124 I-Au@AuCBs has been examined in various cell types (Chinese hamster ovary-CHO; murine dendritic-DC2.4; breast cancer cells-4T1) by proliferation and apoptotic assays. 
Overall, the results show no differences in cell viability; in apoptosis, unlabeled and labeled samples were compared at the concentrations of PEG- ${ }^{124} \mathrm{I}-\mathrm{Au} @ A u C B s$ used, as reported in Figure 6 [126].
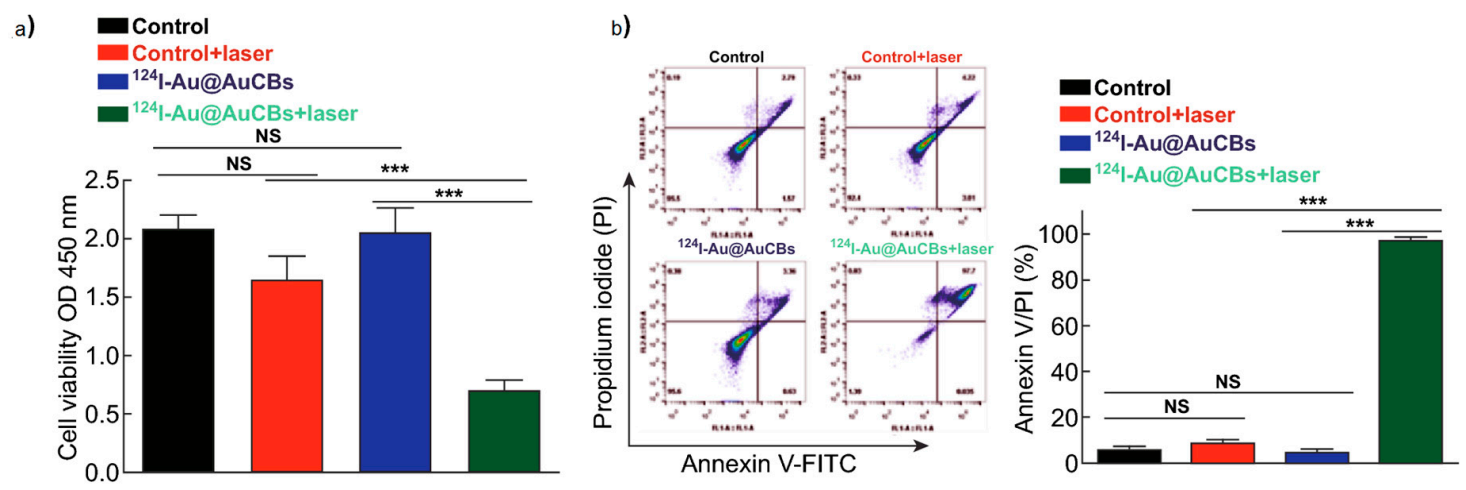

Figure 5. Cytotoxic effects of ${ }^{124} \mathrm{I}-\mathrm{Au} @ \mathrm{AuCBs}$ in colon cancer CT26 cells after photothermal therapy. (a) Analysis of cell viability and (b) apoptosis in irradiated cells via annexin V/PI staining. ${ }^{* * *} p<0.0001$; NS not significant. Reproduced with permission of [125].

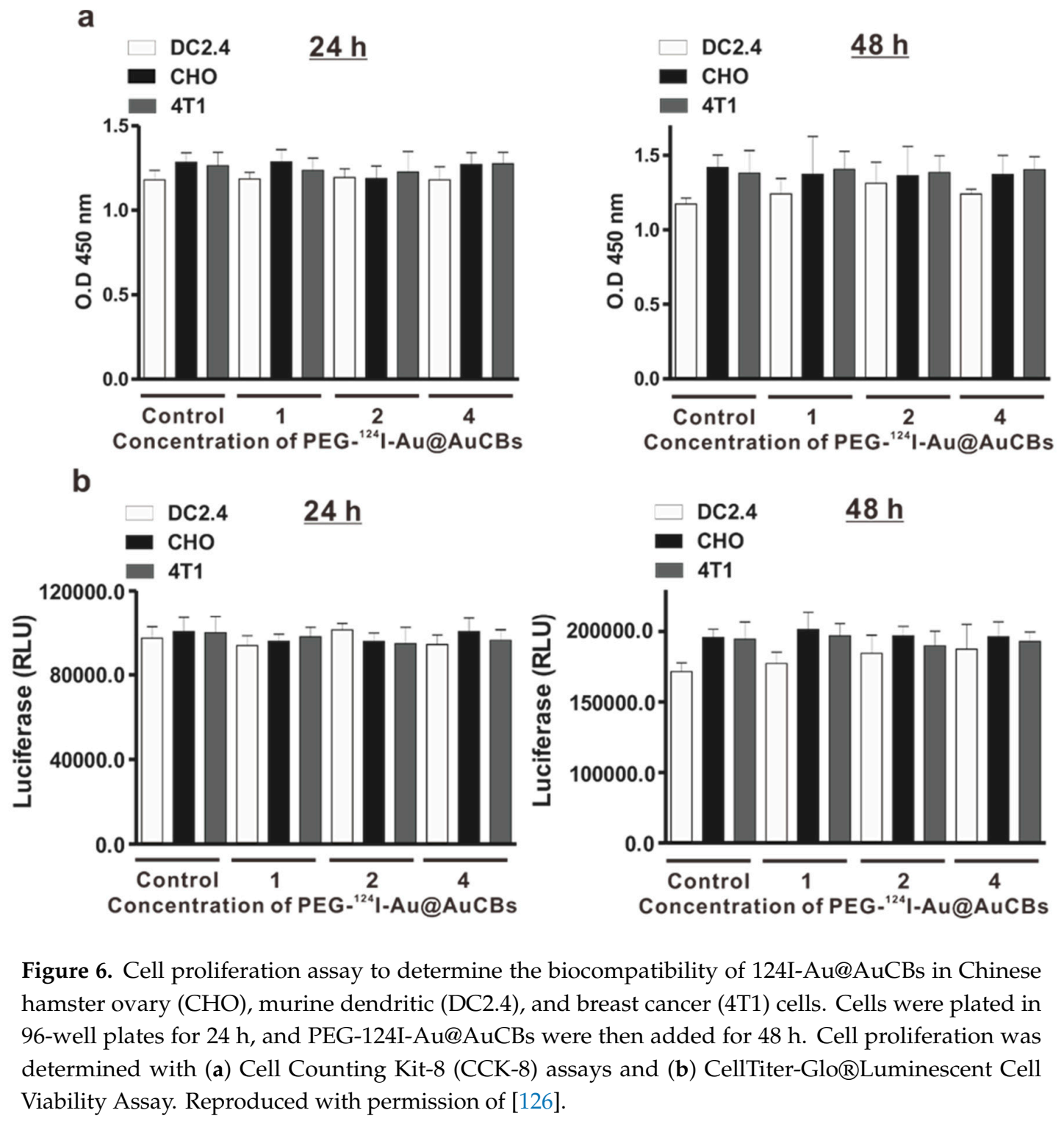


Finally, trastuzumab-211 At-AuNPs exhibited higher cytotoxicity compared to ${ }^{211} \mathrm{At}$-AuNPs. This result encourages the further development of trastuzumab- ${ }^{211} \mathrm{At}-\mathrm{AuNPs}$ as an innovative radiopharmaceutical for local $\alpha$ therapy of HER2-positive cancers due to specific tumor cell binding and high internalization in the tumor [82]. The cytotoxicity of the polyethylenimine-entrapped gold nanoparticles (Au-PE-NPs) functionalized with PEG, chlorotoxin (CTX)—namely, the peptide tumor-targeting ligand-and 3-(4-hydroxyphenyl) propionic acid-OSu (HPAO) has been assessed in glioma C6 cells in terms of proliferation, before and after radiolabeling with ${ }^{131} \mathrm{I}$. The ${ }^{131} \mathrm{I}-\mathrm{Au}-\mathrm{PE}-\mathrm{NPs}-\mathrm{CTX}$ were tested for targeted SPECT imaging and radionuclide therapy in glioma C6 cells. Overall, the results show high viabilities without ${ }^{131}$ I, suggesting good cellular compatibility. On the contrary, after treatment with ${ }^{131} \mathrm{I}$, the $\mathrm{C} 6$ viability decreases in a dose-dependent manner. Also, the cellular uptake is furthered by the addition of the CTX peptide, which occurs through a pathway mediated by receptors. Finally, the targeted specificity has been evaluated by in vitro SPECT imaging. The SPECT signal intensity is increased 4.2-fold in the cells treated with the ${ }^{131} \mathrm{IAu}-\mathrm{PE}-\mathrm{NPs}-\mathrm{CTX}$ compared to those treated with the ${ }^{131} \mathrm{I}-\mathrm{Au}-\mathrm{PE}-\mathrm{NPs}$, as reported in Figure 7 [127].

a)

b)

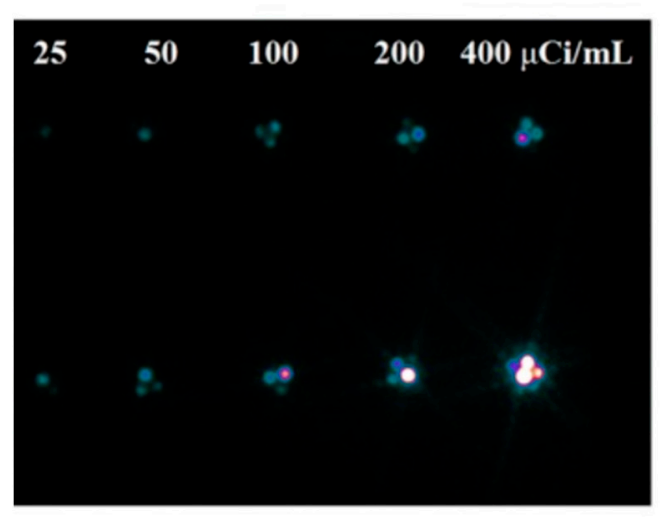

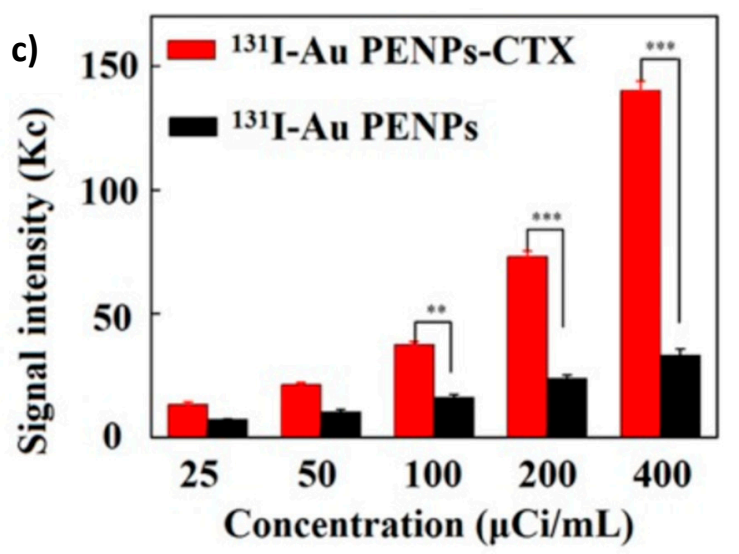

Figure 7. In vitro single-photon emission computed tomography (SPECT) images of glioma C6 cells treated with (a) ${ }^{131} \mathrm{I}-\mathrm{Au}$ polyethylenimine-entrapped gold nanoparticles (PE-NPs) and (b) ${ }^{131} \mathrm{I}-\mathrm{Au}$. PENPs- chlorotoxin (CTX) for $4 \mathrm{~h}$ at the radioactive concentrations of $25 \mu \mathrm{Ci} / \mathrm{mL}, 50 \mu \mathrm{Ci} / \mathrm{mL}, 100$ $\mu \mathrm{Ci} / \mathrm{mL}, 200 \mu \mathrm{Ci} / \mathrm{mL}$, and $400 \mu \mathrm{Ci} / \mathrm{mL}$, respectively, and (c) their relative SPECT signal intensities. Adapted with permission of [127].

The technetium $(\mathrm{Tc})$ is the radionuclide that is most used in nuclear medicine for diagnostic investigations with SPECT. For this reason, in the age of nanomedicine, it becomes very important to be able to combine it with nanostructures. In a recent paper, the dendrimer-entrapped AuNPs (Au DENPs), labeled with ${ }^{99} \mathrm{~m} \mathrm{Tc}$ and functionalized with duramycin, are tested in vitro using SPECT/CT imaging, in order to detect tumor apoptosis in glioma $\mathrm{C} 6$ cells after doxorubicin treatment. Duramycin has a high specificity in recognizing the phospholipid phosphatidylserine (PS), which is present on the outer surface of the cellular membrane of apoptotic cells. The results show that SPECT images of apoptotic C6 cells treated with the 99mTc-duramycin-Au DENPs are much brighter than those of apoptotic C6 cells treated with the ${ }^{99 \mathrm{~m}}$ Tc-duramycin-Au DENPs [128].

Another important aspect of the AuNPs and AuNRs used in nuclear medicine and which need careful in vitro evaluation is their uptake inside the cell, because this key point may also depend on the cell type under consideration. In effect, the uptake of ${ }^{198}$ AuNPs in HepG2 cells and in Madin-Darby canine kidney (MDCK) has shown a dose-dependent internalization in both cell lines, but with a different trend. Moreover, the uptake in HepG2 cells is higher compared to uptake in MDCK cells [129]. The uptake of ${ }^{68} \mathrm{Ga}-A u N P s$ with bombesin (BBN) and the Lys-urea-Glu motif (LUG), which binds the gastrin-releasing peptide receptor (GRPR) and the prostate-specific membrane antigen (PSMA) in PC3, A431, and LNCaP cells, is evaluated. Figure 8 shows these obtained results. [130]. 

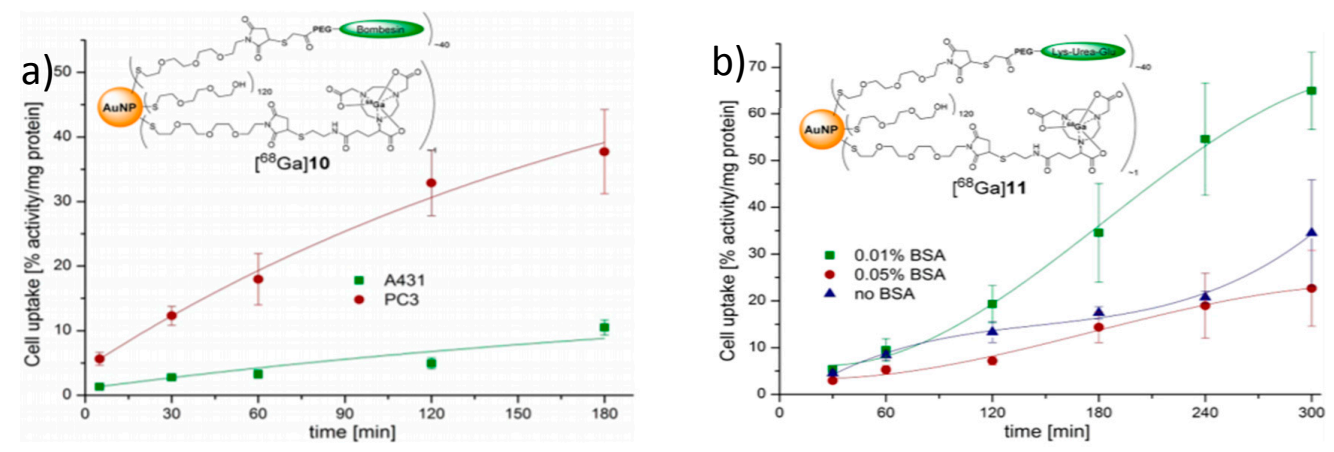

Figure 8. Cell uptake studies. (a) Uptake of gastrin-releasing peptide receptor (GRPR)-specific AuNP $\left[{ }^{68} \mathrm{Ga}\right] 10$ into GRPR-positive PC3 cells (red) compared to GRPR-negative A431 cells (green). (b) Uptake of AuNP [ $\left.{ }^{68} \mathrm{Ga}\right] 11$ into LNCaP cells at different BSA concentrations. Adapted with permission from [130].

The cellular in vitro uptake of ${ }^{131} \mathrm{I}-\mathrm{AuNRs}$ conjugated with cyclic RGD (namely, a peptide targeting a cell adhesion molecule integrin $\alpha_{v} \beta_{3}$ ) in B16F10 mouse malignant melanoma cells (positive for integrin $\alpha_{v} \beta_{3}$ ) and MCF-7 human breast cancer cells (negative for integrin $\alpha_{v} \beta_{3}$ ) has been studied. The result shows a strong uptake in the first ones compared to the last ones, and this confirms that the internalization occurs through receptor-mediated endocytosis [91].

Also, the uptake of AuNPs $(\varnothing=56.37 \pm 3.04 \mathrm{~nm})$ and AuNRs $(22.41 \pm 1.01 \mathrm{~nm}$ in diameter and $56.12 \pm 3.22 \mathrm{~nm}$ in length) labeled with ${ }^{125} \mathrm{I}$ and with addition of $\alpha_{v} \beta_{3}$ integrin-targeted and cisplatin has been evaluated in H1299 cells. The results show a high cell uptake of the AuNRs with respect to AuNPs, indicating that the shape could influence the uptake into cells. Furthermore, the study shows a greater therapeutic efficacy of NRs compared to NPs assessed in terms of cell viability in vitro and the $\gamma-\mathrm{H} 2 \mathrm{AX}$ induction ex vivo, which is probably due to their rapid spread in the tumor interstitial [131].

The uptake of AuNPs labeled with ${ }^{99 \mathrm{~m}} \mathrm{Tc}-\mathrm{TOC}$ and conjugated to either Lys3-BBN, cyclo [Arg-Gly-Asp-D-Phe-Lys-(Cys)] (c[RGDfK(C)]) or thiol-mannose, in $\alpha_{v} \beta_{3}$ receptor-positive C6 glioma cancer cells, GRP-r-positive PC3 cancer cells, or mannose receptor-positive rat liver cells, has been evaluated in order to verify the specific target recognition. In all cases, the uptake of radiopharmaceutical ${ }^{99 \mathrm{~m}} \mathrm{Tc}-\mathrm{AuNP}$ conjugated with Lys3-BBN or c[RGDfK(C)] or mannose, has been significantly higher with respect to ${ }^{99 \mathrm{~m}} \mathrm{Tc}-\mathrm{AuNP}$ only [87].

\section{Gold Nanoparticle and Nanorods: Clinical Aspects}

In view of their chemical and biological features, AuNPs and AuNRs can be labeled with several radionuclides, and have been proposed as innovative tools for diagnostic imaging, for the targeted delivery of drugs, and for the radio treatment of several cancer types [31,132]. The different diagnostic and therapeutic applications of a single molecule/substance are now called theragnostic applications [133], which is one of the most promising fields of nuclear medicine [31]. Radiolabeled gold based nanomaterials have been designed to be able to link the target of interest with the highest binding specificity; however, each AuNP or AuNR showed different behavior based on its individual physical and biological properties, remaining on the cell surface or accumulating inside the cells [81].

Several radionuclides have been proposed to label AuNPs: ${ }^{198} \mathrm{Au},{ }^{125} \mathrm{I},{ }^{111} \mathrm{In},{ }^{64} \mathrm{Cu},{ }^{68} \mathrm{Ga}$, and ${ }^{99} \mathrm{~m} \mathrm{Tc}$ [31]. Depending on the physical properties of the radionuclide, the diagnostic imaging has different characteristics: $\gamma$-emitting radionuclides provide single-photon emission computed tomography (SPECT) imaging $[87,91,97,134,135]$, while $\beta+$-emitting radionuclides provide positron emission tomography (PET) imaging $[41,88]$ or Cerenkov luminescence imaging [81]. When a $\beta$-emitting radionuclide is used, its application is "radiometabolic therapy". Most of the AuNPs were firstly studied in vitro to optimize the synthesis, and were then considered for pre-clinical evaluation to analyze the biodistribution, target uptake, and intralesional distribution. Despite a huge amount of research, no radiolabeled AuNPs have reached the human administration or final authorization for clinical use (by the Food and Drug Administration in the United States, or by the European Medicines Agency in Europe). 


\subsection{Radionuclide ${ }^{198} \mathrm{Au}$}

Black et al. [81] provided an overview of AuNPs with different forms (nanospheres, nanodisks, nanorods, and cubic nanocages) incorporating radioactive Au. Studying a murine EMT6 breast cancer model, ${ }^{198} \mathrm{Au}$-labeled AuNPs were imaged by the Cerenkov signal. Both ${ }^{198} \mathrm{Au}$ nanospheres and nanodisks were found on the surfaces of the tumors, while ${ }^{198} \mathrm{Au}$ nanorods and nanocages were located inside the tumors. ${ }^{198} \mathrm{Au}$ was used to functionalize the prostate tumor-specific epigallocatechin-gallate (EGCg) with AuNPs ( ${ }^{198}$ AuNP-EGCg) to deliver a targeted therapy to the prostate gland using the $\beta$ emission. Pharmacokinetic studies showed about $72 \%$ of ${ }^{198}$ AuNP-EGCg uptake in SCID mice bearing PC-3 tumors 24 hours after the intratumoral injection. The therapeutic effect was a significant inhibition of the tumor growth, with an $80 \%$ decrease of tumor volumes after 28 days [136].

\subsection{Radionuclide ${ }^{125} I$}

Pure $\gamma$ emitter. AuNRs were conjugated to the tumor necrosis factor (TNF- $\alpha$ ) antibody and radiolabeled with ${ }^{125} \mathrm{I}$ by a simpler, green, and unsophisticated method by Agarwal et al. [97]. Since TNF- $\alpha$ is highly concentrated in inflamed tissues, AuNRs conjugated with anti-TNF- $\alpha$ were aimed at quantitatively characterizing the degree of inflammation within joints affected by rheumatoid arthritis as well as monitoring drug delivery. Indeed, Agarwal et al. obtained a hybrid imaging (SPECT/CT) to demonstrate the distribution of these AuNRs in the articular tissues of the rat tail joints. ${ }^{125} \mathrm{I}$ was also used to radiolabel AuNRs conjugated to anti-intercellular adhesion molecule 1 (ICAM-1) antibody. Imaging was obtained through a $\gamma$ camera, evaluating an induced arthritic rat model, which presented higher levels of ICAM-1 in the affected ankle joints [92]. Another approach was to radiolabel AuNPs with ${ }^{125} \mathrm{I}$ and ${ }^{111} \mathrm{In}$ (another $\gamma$ emitter with some Auger electrons) and to functionalize it with a peptide matrix metalloproteinase (pMMP9), resulting in a multispectral SPECT imaging agent. Studies on phantoms and on mice bearing two types of tumors with differing pMMP9 levels were performed to differentiate tumors with different MMP9 expressions [137].

\subsection{Radionuclide ${ }^{99 m} \mathrm{Tc}$}

Pure $\gamma$ emitter. Technetium-99m-labeled AuNPs conjugated to the hydrazinonicotinamideGly-Gly-Cys-NH2 (HYNIC-GGC) peptide and to a thiol-triazole-mannose ( $\left.{ }^{99 \mathrm{~m}} \mathrm{Tc}-\mathrm{AuNP}-\mathrm{mannose}\right)$ showed high specific activity and satisfactory pharmacokinetics for targeted imaging: ${ }^{99} \mathrm{~m}$ Tc-AuNP-mannose, showing a radiochemical purity of $\geq 95 \%$, was demonstrated as stable in human serum and in the popliteal lymph node of rats within $24 \mathrm{~h}$ from the injection (see Figure 9). Therefore, ${ }^{99 \mathrm{~m}} \mathrm{Tc}-\mathrm{AuNP}-$ mannose should be considered a valid candidate for the detection of the sentinel lymph nodes [87].

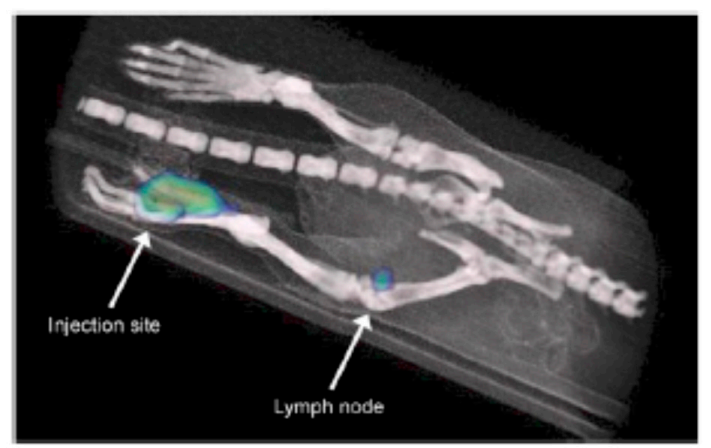

Figure 9. Image obtained from a microSPECT/CT acquisition $2 \mathrm{~h}$ after ${ }^{99 \mathrm{~m}} \mathrm{Tc}-\mathrm{AuNP}-$ mannose injection with the sentinel lymph node identification. Reproduced from [87] with permission from the journal Nuclear Medicine and Biology. 
A recent study aimed to evaluate the synthesis, characterization, and use of ${ }^{99 \mathrm{~m}} \mathrm{Tc}-$ labeled dendrimer-entrapped AuNPs ( ${ }^{99 \mathrm{~m}} \mathrm{Tc}-\mathrm{Au}$ DENPs) for targeted SPECT/CT imaging of chemotherapy-induced tumor apoptosis [128]. Indeed, ${ }^{99 \mathrm{~m}} \mathrm{Tc}-\mathrm{Au}$ DENPs allowed the targeted imaging of apoptotic cancer cells in vitro and of tumor apoptosis after doxorubicin treatment in nude mice bearing C6 glioma cells and xenografted tumors.

\subsection{Integrin $\alpha_{v} \beta_{3}$-Based Targeting}

Integrin $\alpha_{v} \beta_{3}$ is a cell adhesion molecule that is overexpressed in most tumor cells for the regulation of angiogenesis and is involved in different stages of cancer development, such as malignant transformation, tumor growth, invasion, and metastasis. The cyclic arginine-glycine-aspartate acid (RGD) peptide was widely considered to target integrin $\alpha_{\mathrm{v}} \beta_{3}$, showing promising results, in term of higher affinity, selectivity, and stability than linear peptides [91,138]. For these features, the cyclic RGD was also conjugated to AuNPs and then labeled with different radioisotopes as ${ }^{64} \mathrm{Cu}[41],{ }^{111} \mathrm{In}[134]$, and ${ }^{68} \mathrm{Ga}[91,133,139]$ for theragnostic purposes.

\subsubsection{Radionuclide ${ }^{64} \mathrm{Cu}$}

$\beta+$ and $\beta$ - emitter. A simple and chelator-free ${ }^{64} \mathrm{Cu}$ radiolabeling technique was employed to obtain a radiochemically stable ${ }^{64} \mathrm{Cu}$-integrated AuNR with the RGD peptide. This compound showed high tumor affinity in U87MG glioblastoma xenograft model mice, and was efficaciously used for PET image-guided photothermal therapy [41].

\subsubsection{Radionuclide ${ }^{111}$ In}

$\gamma$ emitter with some Auger electrons. In the study of $\mathrm{Ng}$ et al. [134], labeling AuNPs with ${ }^{111}$ In through a direct labeling approach resulted in high activity yield with good stability in the biological setting. Then, their cores were modified on the surface with RGD-based ligands allowing the molecular targeting of the integrin $\alpha_{\mathrm{v}} \beta_{3}$-expressing cells in vitro and SPECT/CT imaging in human melanoma and glioblastoma bearing nude mice in vivo (see Figure 10).

A

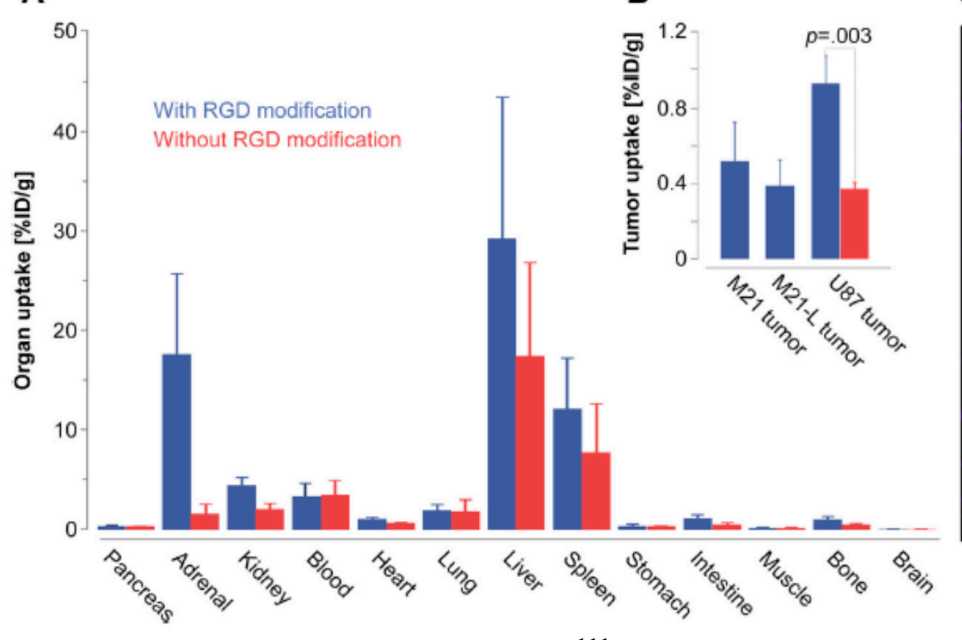

C

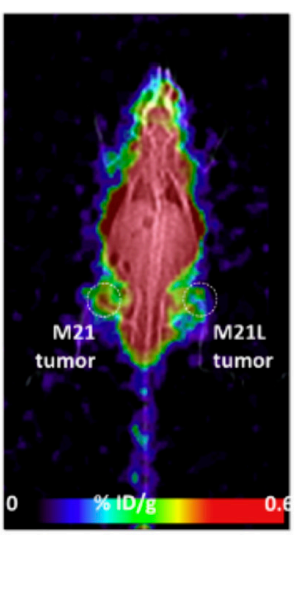

Figure 10. The figure shows in-vivo targeting of ${ }^{111}$ In-cyclic arginine-glycine-aspartate acid (RGD)-based AuNPs. Biodistribution studies were performed in nude mice bearing xenografts of human melanoma (M21: melanoma cells with high $\alpha_{v} \beta_{3}$ integrin expression, M21-L: melanoma cells with high $\alpha_{v} \beta_{3}$ integrin expression) and glioblastoma (U87: glioblastoma cells). Biodistribution was displayed as the percent of injection dose per gram of organ weight (\%ID/g). Each organ (A) and tumor biodistribution (B) demonstrated higher uptake of RGD-modified ${ }^{111}$ In-AuNPs (blue) when compared with the non-targeted AuNPs (red) in the U87 tumor model. Single-photon emission computed tomography (SPECT/CT) imaging (C) showed a higher uptake of RGD-modified ${ }^{111}$ In-AuNPs in the M21 tumor (left) compared to the M21-L tumor (right). Reproduced from [134] with permission from the journal Biomaterials. 


\subsubsection{Radionuclide ${ }^{68} \mathrm{Ga}$}

$\beta+$ emitter. In order to obtain a dual modality positron emission tomography-magnetic resonance imaging (PET/MRI) imaging, a gadolinium chelate-coated AuNP was conjugated to a RGD peptide and radiolabeled with ${ }^{68} \mathrm{Ga}$. Ex vivo biodistribution and in vivo PET and MRI studies in U87MG tumor-bearing SCID mice showed promising results. PET and MRI images were in accordance with the biodistribution data [139].

\subsubsection{Radionuclide ${ }^{131} \mathrm{I}$}

$\gamma$ and $\beta$ - emitter. Recently, Zhang et al. [91] produced ${ }^{131}$ I-labeled AuNRs conjugated to the cyclic RGD for targeting integrin $\alpha_{\mathrm{V}} \beta_{3}$-positive B16F10 cells implanted in mice. Their promising results aim at angiogenesis-targeted SPECT/CT imaging; moreover, the authors suggested a multifunctional theragnostic use in view of this AuNR's intrinsic capacity of photothermal conversion in the near-infrared region.

\subsection{Monoclonal Antibody-Labeled AuNPs}

Monoclonal antibody-labeled AuNPs were considered promising agents for cancer imaging and therapy. To functionalize AuNPs, a good candidate was cetuximab: a mouse-human chimeric monoclonal antibody that binds competitively to the epidermal growth factor receptor (EGFR), which is a tyrosine kinase receptor. In view of EGFR overexpression in many epithelial solid tumors, anticancer therapy against EGFR was already widely studied and applied [96].

\subsubsection{Radionuclide ${ }^{89} \mathrm{Zr}$}

$\beta+$ emitter. Cetuximab was radiolabeled with ${ }^{89} \mathrm{Zr}$ and conjugated to AuNPs with a coupling reaction yield $>75 \%$. Agents were more stable in vitro than in plasma. Evaluation in nude mice bearing human epithelial carcinoma xenografts (A431) revealed no significant difference in terms of tumor uptake for cetuximab conjugated to AuNPs up to 72 hours after the administration, compared to the non-conjugated antibody. Immuno-PET imaging showed a high tumor-to-background ratio [88].

\subsubsection{Radionuclides ${ }^{131} \mathrm{I}$ and ${ }^{123} \mathrm{I}$}

$\gamma$ and $\beta$ - emitter and $\gamma$ emitter, respectively. ${ }^{131}$ I-labeled immuno-AuNP ( ${ }^{131}$ I-C225-AuNPs-PEG) for EGFR-expressed A549 human lung cancer was evaluated in Kao et al.'s study as a promising theragnostic agent [135]. MicroSPECT/CT imaging showed a significant uptake of the compound in tumor-bearing mice. In this paper, the authors concluded that ${ }^{131} \mathrm{I}-\mathrm{C} 225-\mathrm{AuNPs}-\mathrm{PEG}$ might be a valid agent for radioimmunotherapy in EGFR-expressing cancers.

\section{Conclusions}

AuNPs and AuNRs have emerged as promising nanotools in nuclear medicine. The advantages of stability, compatibility in biological environment, easy surface functionalization, and miniaturization have made them good and versatile candidates in therapy and diagnostic applications. In the last few years, they have been increasingly studied in different experimental settings and with interesting results, giving the right premises to see them applied in humans. Finally, we believe that research on AuNPs and AuNRs will have a key role in the development of molecular imaging and radionuclide targeted therapy, both being considered the main development directions toward "personalized medicine".

Author Contributions: Conceptualization, I.V., V.D. and A.G.; writing-original draft preparation, D.M., I.V., V.D. and A.G.; writing—review and editing, D.M., V.D., C.B., I.F., A.C., D.R., M.C., R.F., I.B., T.S., A.G. and I.V.; supervision, I.V.

Funding: This research received no external funding. 
Acknowledgments: The Grant of Excellence Departments, MIUR (ARTICOLO 1, COMMI 314-337 LEGGE 232/2016), is gratefully acknowledged by authors of Roma Tre University.

Conflicts of Interest: The authors declare no conflict of interest.

\section{References}

1. Chen, Q.X.; Liu, Y.H.; Qi, X.Z.; Liu, J.W.; Jiang, H.J.; Wang, J.L.; He, Z.; Ren, X.F.; Hou, Z.H.; Yu, S.H. Ordered Nanostructure Enhances Electrocatalytic Performance by Directional Micro-Electric Field. J. Am. Chem. Soc. 2019, 141, 10729-10735. [CrossRef] [PubMed]

2. Ali, A.K.; Erten-Ela, S.; Hassoon, K.I.; Ela, C. Plasmonic enhancement as selective scattering of gold nanoparticles based dye sensitized solar cells. Thin Solid Films 2019, 671, 127-132. [CrossRef]

3. Naponiello, G.; Venditti, I.; Zardetto, V.; Saccone, D.; Di Carlo, A.; Fratoddi, I.; Barolo, C.; Dini, D. Photoelectrochemical characterization of squaraine-sensitized nickel oxide cathodes deposited via screen-printing for p-type dye-sensitized solar cells. Appl. Surf. Sci. 2015, 356, 911-920. [CrossRef]

4. Song, N.J.; Ma, C. The In-Situ Synthesis of a 3D SnS/N-Doped Graphene Composite with Enhanced Electrochemical Performance as a Low-Cost Anode Material in Sodium Ion Batteries. Materials 2019, 12, 2030. [CrossRef] [PubMed]

5. Bonomo, M.; Naponiello, G.; Venditti, I.; Zardetto, V.; Di Carlo, A.; Dini, D. Electrochemical and Photoelectrochemical Properties of Screen-Printed Nickel Oxide Thin Films Obtained from Precursor Pastes with Different Compositions. J. Electrochem. Soc. 2017, 164, H137-H147. [CrossRef]

6. Yao, J.; Zheng, Y.; Jia, X.; Duan, L.; Wu, Q.; Huang, C.; An, W.; Xu, Q.; Yao, W. Highly Active Pt3Sn $\{110\}$ Excavated Nanocube Cocatalysts for Photocatalytic Hydrogen Production. ACS Appl. Mater. Interfaces 2019, 11, 25844-25853. [CrossRef] [PubMed]

7. Wei, L.; Zhang, J.; Deng, W.; Xie, S.; Zhang, Q.; Wang, Y. Catalytic transformation of 2,5-furandicarboxylic acid to adipic acid over niobic acid-supported Pt nanoparticles. Chem. Commun. 2019, 55, 8013-8016. [CrossRef] [PubMed]

8. Wang, M.; Yang, J.; Liu, S.; Hu, C.; Li, S.; Qiu, J. Polyethyleneimine-Mediated Fabrication of Two-Dimensional Cobalt Sulfide/Graphene Hybrid Nanosheets for High-Performance Supercapacitors. ACS Appl. Mater. Interfaces 2019, 11, 26235-26242. [CrossRef]

9. D'Amato, R.; Venditti, I.; Russo, M.V.; Falconieri, M. Growth control and long-range self-assembly of poly(methyl methacrylate) nanospheres. J. Appl. Polym. Sci. 2006, 102, 4493-4499. [CrossRef]

10. Halamish, H.M.; Trousil, J.; Rak, D.; Knudsen, K.D.; Pavlova, E.; Nyström, B.; Štěpánek, P.; Sosnik, A. Self-assembly and nanostructure of poly(vinyl alcohol)-graft-poly(methyl methacrylate) amphiphilic nanoparticles. J. Coll. Interface Sci. 2019, 553, 512-523. [CrossRef]

11. Venditti, I. Gold Nanoparticles in Photonic Crystals Applications: A Review. Materials 2017, 10, 97. [CrossRef] [PubMed]

12. Cui, W.; Peng, W.; Yu, L.; Luo, X.; Gao, H.; Chu, S.; Masson, J.F. Hybrid Nanodisk Film for Ultra-Narrowband Filtering, Near-Perfect Absorption and Wide Range Sensing. Nanomaterials 2019, 9, 334. [CrossRef] [PubMed]

13. Venditti, I.; D'Amato, R.; Russo, M.V.; Falconieri, M. Synthesis of conjugated polymeric nanobeads for photonic bandgap materials. Sens. Actuators B Chem. 2007, 126, 35-40. [CrossRef]

14. Bardhan, R.; Grady, N.K.; Cole, J.R.; Joshi, A.; Halas, N.J. Fluorescence enhancement by Au nanostructures: Nanoshells and nanorods. ACS Nano 2009, 3, 744-752. [CrossRef] [PubMed]

15. D'Amato, R.; Medei, L.; Venditti, I.; Russo, M.V.; Falconieri, M. Chemical synthesis of polyphenylacetylene nanospheres with controlled dimensions for photonic crystals. Mater. Sci. Eng. C Biomim. Supramol. Syst. 2003, 23, 861-865. [CrossRef]

16. Ayala-Orozco, C.; Liu, J.G.; Knight, M.W.; Wang, Y.; Day, J.K.; Nordlander, P.; Halas, N.J. Fluorescence enhancement of molecules inside a gold nanomatryoshka. Nano Lett. 2014, 14, 2926-2933. [CrossRef] [PubMed]

17. De Angelis, R.; Venditti, I.; Fratoddi, I.; De Matteis, F.; Prosposito, P.; Cacciotti, I.; D'Amico, L.; Nanni, F.; Yadav, A.; Casalboni, M.; et al. From nanospheres to microribbons: Self-assembled Eosin Y doped PMMA nanoparticles as photonic crystals. J. Coll. Interface Sci. 2014, 414, 24-32. [CrossRef]

18. Ganeev, R.A.; Boltaev, G.S.; Kim, V.V.; Guo, C. Effects of Laser Plasma Formation on Quasi-Phase Matching of High-Order Harmonics from Nanoparticles and Atoms. Nanomaterials 2019, 9, 572. [CrossRef] 
19. Wang, Y.; Gu, Z.; Ren, Y.; Wang, Z.; Yao, B.; Dong, Z.; Adamo, G.; Zeng, H.; Sun, H. Perovskite-Ion Beam Interactions: Toward Controllable Light Emission and Lasing. ACS Appl. Mater. Interfaces 2019, 11, 15756-15763. [CrossRef]

20. Tang, T.Y.; Zhou, Y.; Arya, G. Interfacial Assembly of Tunable Anisotropic Nanoparticle Architectures. ACS Nano 2019, 13, 4111-4123. [CrossRef]

21. Pantalei, S.; Zampetti, E.; Macagnano, A.; Bearzotti, A.; Venditti, I.; Russo, M.V. Enhanced sensory properties of a multichannel quartz crystal microbalance coated with polymeric nanobeads. Sensors 2007, 7, 2920-2928. [CrossRef] [PubMed]

22. Imran, M.; Islam, A.U.; Tariq, M.A.; Siddique, M.H.; Shah, N.S.; Khan, Z.U.H.; Amjad, M.; Din, S.U.; Shah, G.M.; Naeem, M.A.; et al. Synthesis of magnetite-based nanocomposites for effective removal of brilliant green dye from wastewater. Environ. Sci. Pollut. Res. Int. 2019, 2019, 1-14. [CrossRef] [PubMed]

23. Bearzotti, A.; Macagnano, A.; Pantalei, S.; Zampetti, E.; Venditti, I.; Fratoddi, I.; Russo, M.V. Alcohol vapor sensory properties of nanostructured conjugated polymers. J. Phys. Condes. Matter 2008, 20, 6. [CrossRef]

24. Santana Vega, M.; Guerrero Martínez, A.; Cucinotta, F. Facile Strategy for the Synthesis of Gold@Silica Hybrid Nanoparticles with Controlled Porosity and Janus Morphology. Nanomaterials 2019, 9, 348. [CrossRef] [PubMed]

25. Loo, J.F.; Lau, P.M.; Kong, S.K.; Ho, H.P. An Assay Using Localized Surface Plasmon Resonance and Gold Nanorods Functionalized with Aptamers to Sense the Cytochrome-c Released from Apoptotic Cancer Cells for Anti-Cancer Drug Effect Determination. Micromachines 2017, 8, 338. [CrossRef] [PubMed]

26. Gormley, A.J.; Greish, K.; Ray, A.; Robinson, R.; Gustafson, J.A.; Ghandehari, H. Gold nanorod mediated plasmonic photothermal therapy: A tool to enhance macromolecular delivery. Int. J. Pharm. 2011, 415, 315-318. [CrossRef] [PubMed]

27. Farooq, M.U.; Novosad, V.; Rozhkova, E.A.; Wali, H.; Ali, A.; Fateh, A.A.; Neogi, P.B.; Neogi, A.; Wang, Z. Gold Nanoparticles-enabled Efficient Dual Delivery of Anticancer Therapeutics to HeLa Cells. Sci. Rep. 2018, 8, 2907. [CrossRef] [PubMed]

28. Porcaro, F.; Carlini, L.; Ugolini, A.; Visaggio, D.; Visca, P.; Fratoddi, I.; Venditti, I.; Meneghini, C.; Simonelli, L.; Marini, C.; et al. Synthesis and Structural Characterization of Silver Nanoparticles Stabilized with 3-Mercapto-1-Propansulfonate and 1-Thioglucose Mixed Thiols for Antibacterial Applications. Materials 2016, 9, 1028. [CrossRef] [PubMed]

29. Mir, M.; Ishtiaq, S.; Rabia, S.; Khatoon, M.; Zeb, A.; Khan, G.M.; Ur Rehman, A.; Ud Din, F. Nanotechnology: From In Vivo Imaging System to Controlled Drug Delivery. Nanoscale Res. Lett. 2017, 12, 500. [CrossRef]

30. Lee, S.B.; Lee, S.W.; Jeong, S.Y.; Yoon, G.; Cho, S.J.; Kim, S.K.; Lee, I.K.; Ahn, B.C.; Lee, J.; Jeon, Y.H. Engineering of Radioiodine-Labeled Gold Core-Shell Nanoparticles as Efficient Nuclear Medicine Imaging Agents for Trafficking of Dendritic Cells. ACS Appl. Mater. Interfaces 2017, 9, 8480-8489. [CrossRef]

31. Same, S.; Aghanejad, A.; Akbari Nakhjavani, S.; Barar, J.; Omidi, Y. Radiolabeled theranostics: Magnetic and gold nanoparticles. Bioimpacts 2016, 6, 169-181. [CrossRef] [PubMed]

32. Moeendarbari, S.; Tekade, R.; Mulgaonkar, A.; Christensen, P.; Ramezani, S.; Hassan, G.; Jiang, R.; Öz, O.K.; Hao, Y.; Sun, X. Theranostic Nanoseeds for Efficacious Internal Radiation Therapy of Unresectable Solid Tumors. Sci. Rep. 2016, 6, 20614. [CrossRef] [PubMed]

33. Nitipir, C.; Niculae, D.; Orlov, C.; Barbu, M.A.; Popescu, B.; Popa, A.M.; Pantea, A.M.S.; Stanciu, A.E.; Galateanu, B.; Ginghina, O.; et al. Update on radionuclide therapy in oncology. Oncol. Lett. 2017, 14, 7011-7015. [PubMed]

34. Mancini-Terracciano, C.; Donnarumma, R.; Bencivenga, G.; Bocci, V.; Cartoni, A.; Collamati, F.; Fratoddi, I.; Giordano, A.; Indovina, L.; Maccora, D.; et al. Feasibility of beta-particle radioguided surgery for a variety of "nuclear medicine" radionuclides. Phys. Med. 2017, 43, 127-133. [CrossRef] [PubMed]

35. Martelli, C.; Marzano, V.; Marini, F.; Scotognella, T.; Fratoddi, I.; Venditti, I.; Rotili, D.; Solfaroli-Camillocci, E.; Collamati, F.; Mancini-Terracciano, C.; et al. Mass spectrometry characterization of DOTA-Nimotuzumab conjugate as precursor of an innovative beta(-) tracer suitable in radio-guided surgery. J. Pharm. Biomed. Anal. 2018, 156, 8-15. [CrossRef] [PubMed]

36. Collamati, F.; Bocci, V.; Castellucci, P.; De Simoni, M.; Fanti, S.; Faccini, R.; Giordano, A.; Maccora, D.; Mancini-Terracciano, C.; Marafini, M.; et al. Radioguided surgery with $\beta$ radiation: A novel application with Ga. Sci. Rep. 2018, 8, 16171. [CrossRef] 
37. Hwang, S.; Nam, J.; Jung, S.; Song, J.; Doh, H.; Kim, S. Gold nanoparticle-mediated photothermal therapy: Current status and future perspective. Nanomedicine 2014, 9, 2003-2022. [CrossRef]

38. Book Newell, B.; Wang, Y.; Irudayaraj, J. Multifunctional gold nanorod theragnostics probed by multi-photon imaging. Eur. J. Med. Chem. 2012, 48, 330-337. [CrossRef]

39. Shim, M.S.; Kim, C.S.; Ahn, Y.C.; Chen, Z.; Kwon, Y.J. Combined multimodal optical imaging and targeted gene silencing using stimuli-transforming nanotheragnostics. J. Am. Chem. Soc. 2010, 132, 8316-8324. [CrossRef]

40. Venditti, I.; Cartoni, A.; Fontana, L.; Testa, G.; Scaramuzzo, F.A.; Faccini, R.; Terracciano, C.M.; Camillocci, E.S.; Morganti, S.; Giordano, A.; et al. Y3+ embedded in polymeric nanoparticles: Morphology, dimension and stability of composite colloidal system. Coll. Surf. A Physicochem. Eng. Asp. 2017, 532, 125-131. [CrossRef]

41. Sun, X.; Huang, X.; Yan, X.; Wang, Y.; Guo, J.; Jacobson, O.; Liu, D.; Szajek, L.P.; Zhu, W.; Niu, G.; et al. Chelator-free (64)Cu-integrated gold nanomaterials for positron emission tomography imaging guided photothermal cancer therapy. ACS Nano 2014, 8, 8438-8446. [CrossRef] [PubMed]

42. Sharma, S. PET Radiopharmaceuticals for Personalized Medicine. Curr. Drug Targets 2016, 17, $1894-1907$. [CrossRef] [PubMed]

43. Dash, A.; Knapp, F.F.; Pillai, M.R. Targeted radionuclide therapy-An overview. Curr. Radiopharm. 2013, 6, 152-180. [CrossRef] [PubMed]

44. Yook, S.; Cai, Z.; Lu, Y.; Winnik, M.A.; Pignol, J.P.; Reilly, R.M. Intratumorally Injected 177Lu-Labeled Gold Nanoparticles: Gold Nanoseed Brachytherapy with Application for Neoadjuvant Treatment of Locally Advanced Breast Cancer. J. Nucl. Med. 2016, 57, 936-942. [CrossRef] [PubMed]

45. Asadi, S.; Vaez-zadeh, M.; Masoudi, S.F.; Rahmani, F.; Knaup, C.; Meigooni, A.S. Gold nanoparticle-based brachytherapy enhancement in choroidal melanoma using a full Monte Carlo model of the human eye. J. Appl. Clin. Med. Phys. 2015, 16, 344-357. [CrossRef] [PubMed]

46. Khan, M.K.; Minc, L.D.; Nigavekar, S.S.; Kariapper, M.S.; Nair, B.M.; Schipper, M.; Cook, A.C.; Lesniak, W.G.; Balogh, L.P. Fabrication of $\{198 \mathrm{Au} 0\}$ radioactive composite nanodevices and their use for nanobrachytherapy. Nanomedicine 2008, 4, 57-69. [CrossRef] [PubMed]

47. Jokerst, J.V.; Gambhir, S.S. Molecular imaging with theranostic nanoparticles. Acc. Chem. Res. 2011, 44, 1050-1060. [CrossRef] [PubMed]

48. Venditti, I. Morphologies and functionalities of polymeric nanocarriers as chemical tools for drug delivery: A review. JKSUS 2019, 31, 398-411. [CrossRef]

49. Venditti, I. Engineered Gold-Based Nanomaterials: Morphologies and Functionalities in Biomedical Applications. A Mini Review. Bioengineering 2019, 6, 53. [CrossRef]

50. Chang, C.C.; Chen, C.P.; Wu, T.H.; Yang, C.H.; Lin, C.W.; Chen, C.Y. Gold Nanoparticle-Based Colorimetric Strategies for Chemical and Biological Sensing Applications. Nanomaterials 2019, 9, 861. [CrossRef]

51. Zong, J.; Cobb, S.L.; Cameron, N.R. Peptide-functionalized gold nanoparticles: Versatile biomaterials for diagnostic and therapeutic applications. Biomater. Sci. 2017, 5, 872-886. [CrossRef] [PubMed]

52. Lee, Y.J.; Song, K.; Cha, S.H.; Cho, S.; Kim, Y.S.; Park, Y. Sesquiterpenoids from Tussilago farfara Flower Bud Extract for the Eco-Friendly Synthesis of Silver and Gold Nanoparticles Possessing Antibacterial and Anticancer Activities. Nanomaterials 2019, 9, 819. [CrossRef] [PubMed]

53. Becker, A.; Leskau, M.; Schlingmann-Molina, B.L.; Hohmeier, S.C.; Alnajjar, S.; Murua Escobar, H.; Ngezahayo, A. Functionalization of gold-nanoparticles by the Clostridium perfringens enterotoxin C-terminus for tumor cell ablation using the gold nanoparticle-mediated laser perforation technique. Sci. Rep. 2018, 8, 14963. [CrossRef] [PubMed]

54. Kim, D.; Jeong, Y.Y.; Jon, S. A Drug-Loaded Aptamer-Gold Nanoparticle Bioconjugate for Combined CT Imaging and Therapy of Prostate Cancer. ACS Nano 2010, 4, 3689-3696. [CrossRef]

55. Fratoddi, I.; Benassi, L.; Botti, E.; Vaschieri, C.; Venditti, I.; Bessar, H.; Samir, M.A.; Azzoni, P.; Magnoni, C.; Costanzo, A.; et al. Effects of topical methotrexate loaded gold nanoparticle in cutaneous inflammatory mouse model. Nanomedicine 2019, 17, 276-286. [CrossRef]

56. Bae, S.H.; Yu, J.; Go, M.R.; Kim, H.J.; Hwang, Y.G.; Choi, S.J. Oral Toxicity and Intestinal Transport Mechanism of Colloidal Gold Nanoparticle-Treated Red Ginseng. Nanomaterials 2016, 6, 208. [CrossRef]

57. Fratoddi, I.; Venditti, I.; Battocchio, C.; Carlini, L.; Amatori, S.; Porchia, M.; Tisato, F.; Bondino, F.; Magnano, E.; Pellei, M.; et al. Highly Hydrophilic Gold Nanoparticles as Carrier for Anticancer Copper(I) Complexes: Loading and Release Studies for Biomedical Applications. Nanomaterials 2019, 9, 772. [CrossRef] 
58. Zhou, B.; Song, J.; Wang, M.; Wang, X.; Wang, J.; Howard, E.W.; Zhou, F.; Qu, J.; Chen, W.R. BSA-bioinspired gold nanorods loaded with immunoadjuvant for the treatment of melanoma by combined photothermal therapy and immunotherapy. Nanoscale 2018, 10, 21640-21647. [CrossRef]

59. Fratoddi, I.; Cartoni, A.; Venditti, I.; Catone, D.; O’Keeffe, P.; Paladini, A.; Toschi, F.; Turchini, S.; Sciubba, F.; Testa, G.; et al. Gold nanoparticles functionalized by rhodamine B isothiocyanate: A new tool to control plasmonic effects. J. Coll. Interface Sci. 2018, 513, 10-19. [CrossRef]

60. Zhang, W.; Caldarola, M.; Lu, X.; Pradhan, B.; Orrit, M. Single-molecule fluorescence enhancement of a near-infrared dye by gold nanorods using DNA transient binding. Phys. Chem. Chem. Phys. 2018, 20, 20468-20475. [CrossRef]

61. Venditti, I.; Testa, G.; Sciubba, F.; Carlini, L.; Porcaro, F.; Meneghini, C.; Mobilio, S.; Battocchio, C.; Fratoddi, I. Hydrophilic Metal Nanoparticles Functionalized by 2-Diethylaminoethanethiol: A Close Look at the Metal-Ligand Interaction and Interface Chemical Structure. J. Phys. Chem. C 2017, 121, 8002-8013. [CrossRef]

62. Rodzik-Czalka, L.; Lewandowska-Lancucka, J.; Gatta, V.; Venditti, I.; Fratoddi, I.; Szuwarzynski, M.; Romek, M.; Nowakowska, M. Nucleobases functionalized quantum dots and gold nanoparticles bioconjugates as a fluorescence resonance energy transfer (FRET) system-Synthesis, characterization and potential applications. J. Coll. Interface Sci. 2018, 514, 479-490. [CrossRef] [PubMed]

63. Chen, Z.; Choi, C.K.K.; Wang, Q. Origin of the Plasmonic Chirality of Gold Nanorod Trimers Templated by DNA Origami. ACS Appl. Mater. Interfaces 2018, 10, 26835-26840. [CrossRef] [PubMed]

64. Rossi, A.; Donati, S.; Fontana, L.; Porcaro, F.; Battocchio, C.; Proietti, E.; Venditti, I.; Bracci, L.; Fratoddi, I. Negatively charged gold nanoparticles as a dexamethasone carrier: Stability in biological media and bioactivity assessment in vitro. RSC Adv. 2016, 6, 99016-99022. [CrossRef]

65. Venditti, I.; Hassanein, T.F.; Fratoddi, I.; Fontana, L.; Battocchio, C.; Rinaldi, F.; Carafa, M.; Marianecci, C.; Diociaiuti, M.; Agostinelli, E.; et al. Bioconjugation of gold-polymer core-shell nanoparticles with bovine serum amine oxidase for biomedical applications. Coll. Surf. B Biointerfaces 2015, 134, 314-321. [CrossRef] [PubMed]

66. Fratoddi, I.; Venditti, I.; Cametti, C.; Russo, M.V. The puzzle of toxicity of gold nanoparticles. The case-study of HeLa cells. Toxicol. Res. 2015, 4, 796-800. [CrossRef]

67. Singh, R.; Patil, S.; Singh, N.; Gupta, S. Dual functionality nanobioconjugates targeting intracellular bacteria in cancer cells with enhanced antimicrobial activity. Sci. Rep. 2017, 7, 5792. [CrossRef]

68. Mendoza, G.; Regiel-Futyra, A.; Andreu, V.; Sebastián, V.; Kyzioł, A.; Stochel, G.; Arruebo, M. Bactericidal Effect of Gold-Chitosan Nanocomposites in Coculture Models of Pathogenic Bacteria and Human Macrophages. ACS Appl. Mater. Interfaces 2017, 9, 17693-17701. [CrossRef]

69. Chowdhury, R.; Ilyas, H.; Ghosh, A.; Ali, H.; Ghorai, A.; Midya, A.; Jana, N.R.; Das, S.; Bhunia, A. Multivalent gold nanoparticle-peptide conjugates for targeting intracellular bacterial infections. Nanoscale 2017, 9, 14074-14093. [CrossRef]

70. Hu, B.; Wang, N.; Han, L.; Chen, M.L.; Wang, J.H. Core-shell-shell nanorods for controlled release of silver that can serve as a nanoheater for photothermal treatment on bacteria. Acta Biomater. 2015, 11, 511-519. [CrossRef]

71. Lin, S.Y.; Wu, S.H.; Chen, C.H. A simple strategy for prompt visual sensing by gold nanoparticles: General applications of interparticle hydrogen bonds. Angew. Chem. Int. Ed. Engl. 2006, 45, 4948-4951. [CrossRef] [PubMed]

72. Herizchi, R.; Abbasi, E.; Milani, M.; Akbarzadeh, A. Current methods for synthesis of gold nanoparticles. Artif. Cells Nanomed. Biotechnol. 2016, 44, 596-602. [CrossRef] [PubMed]

73. Wuithschick, M.; Birnbaum, A.; Witte, S.; Sztucki, M.; Vainio, U.; Pinna, N.; Rademann, K.; Emmerling, F.; Kraehnert, R.; Polte, J. Turkevich in New Robes: Key Questions Answered for the Most Common Gold Nanoparticle Synthesis. ACS Nano 2015, 9, 7052-7071. [CrossRef] [PubMed]

74. Booth, S.G.; Uehara, A.; Chang, S.Y.; La Fontaine, C.; Fujii, T.; Okamoto, Y.; Imai, T.; Schroeder, S.L.M.; Dryfe, R.A.W. The significance of bromide in the Brust-Schiffrin synthesis of thiol protected gold nanoparticles. Chem. Sci. 2017, 8, 7954-7962. [CrossRef] [PubMed]

75. Arvizo, R.; Bhattacharya, R.; Mukherjee, P. Gold nanoparticles: Opportunities and challenges in nanomedicine. Expert Opin. Drug Deliv. 2010, 7, 753-763. [CrossRef] [PubMed]

76. Jeremic, B.; Aguerri, A.R.; Filipovic, N. Radiosensitization by gold nanoparticles. Clin. Transl. Oncol. 2013, 15, 593-601. [CrossRef] [PubMed] 
77. Xu, W.; Luo, T.; Li, P.; Zhou, C.; Cui, D.; Pang, B.; Ren, Q.; Fu, S. RGD-conjugated gold nanorods induce radiosensitization in melanoma cancer cells by downregulating $\alpha(\mathrm{v}) \beta_{3}$ expression. Int. J. Nanomed. 2012, 7, 915-924.

78. Catone, D.; Ciavardini, A.; Di Mario, L.; Paladini, A.; Toschi, F.; Cartoni, A.; Fratoddi, I.; Venditti, I.; Alabastri, A.; Zaccaria, R.P.; et al. Plasmon Controlled Shaping of Metal Nanoparticle Aggregates by Femtosecond Laser-Induced Melting. J. Phys. Chem. Lett. 2018, 9, 5002-5008. [CrossRef]

79. Chen, S.; Yang, K.; Tuguntaev, R.G.; Mozhi, A.; Zhang, J.; Wang, P.C.; Liang, X.J. Targeting tumor microenvironment with PEG-based amphiphilic nanoparticles to overcome chemoresistance. Nanomedicine 2016, 12, 269-286. [CrossRef]

80. Zhao, L.; Wen, S.; Zhu, M.; Li, D.; Xing, Y.; Shen, M.; Shi, X.; Zhao, J. Tc-labelled multifunctional polyethylenimine-entrapped gold nanoparticles for dual mode SPECT and CT imaging. Artif. Cells Nanomed. Biotechnol. 2018, 46 (Suppl. 1), 488-498. [CrossRef]

81. Black, K.C.; Wang, Y.; Luehmann, H.P.; Cai, X.; Xing, W.; Pang, B.; Zhao, Y.; Cutler, C.S.; Wang, L.V.; Liu, Y.; et al. Radioactive 198Au-doped nanostructures with different shapes for in vivo analyses of their biodistribution, tumor uptake, and intratumoral distribution. ACS Nano 2014, 8, 4385-4394. [CrossRef] [PubMed]

82. Dziawer, Ł.; Majkowska-Pilip, A.; Gaweł, D.; Godlewska, M.; Pruszyński, M.; Jastrzębski, J.; Wąs, B.; Bilewicz, A. Trastuzumab-Modified Gold Nanoparticles Labeled with 211At as a prospective tool for local treatment of HER2-positive breast cancer. Nanomaterials 2019, 9, 632. [CrossRef] [PubMed]

83. Li, X.; Wang, C.; Tan, H.; Cheng, L.; Liu, G.; Yang, Y.; Zhao, Y.; Zhang, Y.; Li, Y.; Zhang, C.; et al. Gold nanoparticles-based SPECT/CT imaging probe targeting for vulnerable atherosclerosis plaques. Biomaterials 2016, 108, 71-80. [CrossRef] [PubMed]

84. Zhao, Y.; Pang, B.; Luehmann, H.; Detering, L.; Yang, X.; Sultan, D.; Harpstrite, S.; Sharma, V.; Cutler, C.S.; Xia, Y.; et al. Gold Nanoparticles Doped with (199) Au Atoms and Their Use for Targeted Cancer Imaging by SPECT. Adv. Healthc. Mater. 2016, 5, 928-935. [CrossRef] [PubMed]

85. Zhou, B.; Wang, R.; Chen, F.; Zhao, L.; Wang, P.; Li, X.; Bányai, I.; Ouyang, Q.; Shi, X.; Shen, M. Tc-Labeled RGD-Polyethylenimine Conjugates with Entrapped Gold Nanoparticles in the Cavities for Dual-Mode SPECT/CT Imaging of Hepatic Carcinoma. ACS Appl. Mater. Interfaces 2018, 10, 6146-6154. [CrossRef] [PubMed]

86. Yook, S.; Lu, Y.; Jeong, J.J.; Cai, Z.; Tong, L.; Alwarda, R.; Pignol, J.P.; Winnik, M.A.; Reilly, R.M. Stability and Biodistribution of Thiol-Functionalized and (177)Lu-Labeled Metal Chelating Polymers Bound to Gold Nanoparticles. Biomacromolecules 2016, 17, 1292-1302. [CrossRef]

87. Ocampo-García, B.E.; Ramírez, F.E.M.; Ferro-Flores, G.; De León-Rodríguez, L.M.; Santos-Cuevas, C.L.; Morales-Avila, E.; de Murphy, C.A.; Pedraza-López, M.; Medina, L.A.; Camacho-López, M.A. (99m)Tc-labelled gold nanoparticles capped with HYNIC-peptide/mannose for sentinel lymph node detection. Nucl. Med. Biol. 2011, 38, 1-11. [CrossRef]

88. Karmani, L.; Labar, D.; Valembois, V.; Bouchat, V.; Nagaswaran, P.G.; Bol, A.; Gillart, J.; Levêque, P.; Bouzin, C.; Bonifazi, D.; et al. Antibody-functionalized nanoparticles for imaging cancer: Influence of conjugation to gold nanoparticles on the biodistribution of $89 \mathrm{Zr}$-labeled cetuximab in mice. Contrast Media Mol. Imaging 2013, 8, 402-408. [CrossRef]

89. Zhu, J.; Chin, J.; Wängler, C.; Wängler, B.; Lennox, R.B.; Schirrmacher, R. Rapid (18)F-labeling and loading of PEGylated gold nanoparticles for in vivo applications. Bioconjug Chem. 2014, 25, 1143-1150. [CrossRef]

90. Khoo, A.M.; Cho, S.H.; Reynoso, F.J.; Aliru, M.; Aziz, K.; Bodd, M.; Yang, X.; Ahmed, M.F.; Yasar, S.; Manohar, N.; et al. Radiosensitization of Prostate Cancers In Vitro and In Vivo to Erbium-filtered Orthovoltage X-rays Using Actively Targeted Gold Nanoparticles. Sci. Rep. 2017, 7, 18044. [CrossRef]

91. Zhang, Y.; Yin, L.; Xia, X.; Hu, F.; Liu, Q.; Qin, C.; Lan, X. Synthesis and Bioevaluation of Iodine-131 Directly Labeled Cyclic RGD-PEGylated Gold Nanorods for Tumor-Targeted Imaging. Contrast Media Mol. Imaging 2017, 2017, 6081724. [CrossRef] [PubMed]

92. Shao, X.; Zhang, H.; Rajian, J.R.; Chamberland, D.L.; Sherman, P.S.; Quesada, C.A.; Koch, A.E.; Kotov, N.A.; Wang, X. 125I-labeled gold nanorods for targeted imaging of inflammation. ACS Nano 2011, 5, 8967-8973. [CrossRef] [PubMed] 
93. Zhang, L.; Su, H.; Cai, J.; Cheng, D.; Ma, Y.; Zhang, J.; Zhou, C.; Liu, S.; Shi, H.; Zhang, Y.; et al. A Multifunctional Platform for Tumor Angiogenesis-Targeted Chemo-Thermal Therapy Using Polydopamine-Coated Gold Nanorods. ACS Nano 2016, 10, 10404-10417. [CrossRef] [PubMed]

94. Buckway, B.; Frazier, N.; Gormley, A.J.; Ray, A.; Ghandehari, H. Gold nanorod-mediated hyperthermia enhances the efficacy of HPMA copolymer-90Y conjugates in treatment of prostate tumors. Nucl. Med. Biol. 2014, 41, 282-289. [CrossRef] [PubMed]

95. Eskandari, N.; Yavari, K.; Outokesh, M.; Sadjadi, S.; Ahmadi, S.J. Iodine-131 radiolabeling of poly ethylene glycol-coated gold nanorods for in vivo imaging. J. Label. Comp. Radiopharm. 2013, 56, 12-16. [CrossRef] [PubMed]

96. Shao, X.; Agarwal, A.; Rajian, J.R.; Kotov, N.A.; Wang, X. Synthesis and bioevaluation of ${ }^{125}$ I-labeled gold nanorods. Nanotechnology 2011, 22, 135102. [CrossRef] [PubMed]

97. Agarwal, A.; Shao, X.; Rajian, J.R.; Zhang, H.; Chamberland, D.L.; Kotov, N.A.; Wang, X. Dual-mode imaging with radiolabeled gold nanorods. J. Biomed. Opt. 2011, 16, 051307. [CrossRef] [PubMed]

98. Matassa, R.; Familiari, G.; Battaglione, E.; Sibilia, C.; Leahu, G.; Belardini, A.; Venditti, I.; Fontana, L.; Fratoddi, I. Electron microscopy reveals a soluble hybrid network of individual nanocrystals self-anchored by bifunctional thiol fluorescent bridges. Nanoscale 2016, 8, 18161-18169. [CrossRef] [PubMed]

99. Kluenker, M.; Mondeshki, M.; Nawaz Tahir, M.; Tremel, W. Monitoring Thiol-Ligand Exchange on Au Nanoparticle Surfaces. Langmuir 2018, 34, 1700-1710. [CrossRef]

100. Balasubramanian, S.K.; Yang, L.; Yung, L.Y.; Ong, C.N.; Ong, W.Y.; Yu, L.E. Characterization, purification, and stability of gold nanoparticles. Biomaterials 2010, 31, 9023-9030. [CrossRef]

101. Goldstein, A.; Soroka, Y.; Frušić-Zlotkin, M.; Popov, I.; Kohen, R. High resolution SEM imaging of gold nanoparticles in cells and tissues. J. Microsc. 2014, 256, 237-247. [CrossRef] [PubMed]

102. Grobelny, J.; DelRio, F.W.; Pradeep, N.; Kim, D.I.; Hackley, V.A.; Cook, R.F. Size measurement of nanoparticles using atomic force microscopy. Methods Mol. Biol. 2011, 697, 71-82. [PubMed]

103. Porcaro, F.; Battocchio, C.; Antoccia, A.; Fratoddi, I.; Venditti, I.; Fracassi, A.; Luisetto, I.; Russo, M.V.; Polzonetti, G. Synthesis of functionalized gold nanoparticles capped with 3-mercapto-1-propansulfonate and 1-thioglucose mixed thiols and "in vitro" bioresponse. Coll. Surf. B Biointerfaces 2016, 142, 408-416. [CrossRef] [PubMed]

104. Bandyopadhyay, S.; McDonagh, B.H.; Singh, G.; Raghunathan, K.; Sandvig, A.; Sandvig, I.; Andreassen, J.P.; Glomm, W.R. Growing gold nanostructures for shape-selective cellular uptake. Nanoscale Res. Lett. 2018, 13, 254. [CrossRef] [PubMed]

105. Kuo, B.H.; Hsia, C.F.; Chen, T.N.; Huang, M.H. Systematic Shape Evolution of Gold Nanocrystals Achieved through Adjustment in the Amount of HAuCl4 Solution Used. J. Phys. Chem. C 2018, 122, 25118-25126. [CrossRef]

106. Carlini, L.; Fasolato, C.; Postorino, P.; Fratoddi, I.; Venditti, I.; Testa, G.; Battocchio, C. Comparison between silver and gold nanoparticles stabilized with negatively charged hydrophilic thiols: SR-XPS and SERS as probes for structural differences and similarities. Coll. Surf. A Physicochem. Eng. Asp. 2017, 532, 183-188. [CrossRef]

107. Langille, M.R.; Personick, M.L.; Zhang, J.; Mirkin, C.A. Defining rules for the shape evolution of gold nanoparticles. J. Am. Chem. Soc. 2012, 134, 14542-14554. [CrossRef]

108. Zheng, Y.; Ma, Y.; Zeng, J.; Zhong, X.; Jin, M.; Li, Z.Y.; Xia, Y. Seed-mediated synthesis of single-crystal gold nanospheres with controlled diameters in the range $5-30 \mathrm{~nm}$ and their self-assembly upon dilution. Chem. Asian J. 2013, 8, 792-799. [CrossRef]

109. Prosposito, P.; Mochi, F.; Ciotta, E.; Casalboni, M.; De Matteis, F.; Venditti, I.; Fontana, L.; Testa, G.; Fratoddi, I. Hydrophilic silver nanoparticles with tunable optical properties: Application for the detection of heavy metals in water. Beilstein J. Nanotechnol. 2016, 7, 1654-1661. [CrossRef]

110. Mochi, F.; Burratti, L.; Fratoddi, I.; Venditti, I.; Battocchio, C.; Carlini, L.; Iucci, G.; Casalboni, M.; de Matteis, F.; Casciardi, S.; et al. Plasmonic Sensor Based on Interaction between Silver Nanoparticles and $\mathrm{Ni}^{2+} \mathrm{or}^{2+}$ in Water. Nanomaterials 2018, 8, 488. [CrossRef]

111. Sriram, M.; Zong, K.; Vivekchand, S.R.; Gooding, J.J. Single nanoparticle plasmonic sensors. Sensors 2015, 15, 25774-25792. [CrossRef] [PubMed]

112. Jo, S.D.; Ku, S.H.; Won, Y.Y.; Kim, S.H.; Kwon, I.C. Targeted Nanotheranostics for Future Personalized Medicine: Recent Progress in Cancer Therapy. Theranostics 2016, 6, 1362-1377. [CrossRef] [PubMed] 
113. Park, K.; Hsiao, M.S.; Yi, Y.J.; Izor, S.; Koerner, H.; Jawaid, A.; Vaia, R.A. Highly Concentrated Seed-Mediated Synthesis of Monodispersed Gold Nanorods. ACS Appl. Mater. Interfaces 2017, 9, 26363-26371. [CrossRef] [PubMed]

114. Tong, X.; Wang, Z.; Sun, X.; Song, J.; Jacobson, O.; Niu, G.; Kiesewetter, D.O.; Chen, X. Size Dependent Kinetics of Gold Nanorods in EPR Mediated Tumor Delivery. Theranostics 2016, 6, 2039-2051. [CrossRef] [PubMed]

115. Dahan, D.; Jude, B.A.; Lamendella, R.; Keesing, F.; Perron, G.G. Exposure to Arsenic Alters the Microbiome of Larval Zebrafish. Front. Microbiol. 2018, 9, 1323. [CrossRef] [PubMed]

116. Brown, Z.B.; Takagi, J. Advances in domain and subunit localization technology for electron microscopy. Biophys. Rev. 2019, 11, 149-155. [CrossRef] [PubMed]

117. Connor, E.E.; Mwamuka, J.; Gole, A.; Murphy, C.J.; Wyatt, M.D. Gold nanoparticles are taken up by human cells but do not cause acute cytotoxicity. Small 2005, 1, 325-357. [CrossRef] [PubMed]

118. Goel, R.; Shah, N.; Visaria, R.; Paciotti, G.F.; Bischof, J.C. Biodistribution of TNF-alpha-coated gold nanoparticles in an in vivo model system. Nanomedicine 2009, 4, 401-410. [CrossRef]

119. Wan, J.; Wang, J.H.; Liu, T.; Xie, Z.; Yu, X.F.; Li, W. Surface chemistry but not aspect ratio mediates the biological toxicity of gold nanorods in vitro and in vivo. Sci. Rep. 2015, 5, 11398. [CrossRef]

120. Repetto, G.; del Peso, A.; Zurita, J.L. Neutral red uptake assay for the estimation of cell viability/cytotoxicity. Nat. Protoc. 2008, 3, 1125-1131. [CrossRef]

121. Kumar, V.; Sharma, N.; Maitra, S.S. In vitro and in vivo toxicity assessment of nanoparticles. Int. Nano Lett. 2017, 7, 243-256. [CrossRef]

122. Iram, F.; Iqbal, M.S.; Khan, I.U.; Rasheed, R.; Khalid, A.; Khalid, M.; Aftab, S.; Shakoori, A.R. Synthesis and Biodistribution Study of Biocompatible. Biol. Trace Elem. Res. 2019, 2019, 1-12.

123. Lee, S.B.; Yoon, G.; Lee, S.W.; Jeong, S.Y.; Ahn, B.C.; Lim, D.K.; Lee, J.; Jeon, Y.H. Combined Positron Emission Tomography and Cerenkov Luminescence Imaging of Sentinel Lymph Nodes Using PEGylated Radionuclide-Embedded Gold Nanoparticles. Small 2016, 12, 4894-4901. [CrossRef] [PubMed]

124. Wójtowicz, A.; Krug, P.; Głowala, P.; Hungría, A.B.; Chotkowski, M.; Wiktorska, K.; Mazur, M. Nano-radiogold-decorated composite bioparticles. Mater. Sci. Eng. C Mater. Biol. Appl. 2019, 97, 768-775. [CrossRef] [PubMed]

125. Lee, S.B.; Lee, J.E.; Cho, S.J.; Chin, J.; Kim, S.K.; Lee, I.K.; Lee, S.W.; Lee, J.; Jeon, Y.H. Crushed Gold Shell Nanoparticles Labeled with Radioactive Iodine as a Theranostic Nanoplatform for Macrophage-Mediated Photothermal Therapy. Nano Micro Lett. 2019, 11, 36. [CrossRef]

126. Lee, S.B.; Kumar, D.; Li, Y.; Lee, I.K.; Cho, S.J.; Kim, S.K.; Lee, S.W.; Jeong, S.Y.; Lee, J.; Jeon, Y.H. PEGylated crushed gold shell-radiolabeled core nanoballs for in vivo tumor imaging with dual positron emission tomography and Cerenkov luminescent imaging. J. Nanobiotechnol. 2018, 16, 41. [CrossRef]

127. Zhao, L.; Li, Y.; Zhu, J.; Sun, N.; Song, N.; Xing, Y.; Huang, H.; Zhao, J. Chlorotoxin peptide-functionalized polyethylenimine-entrapped gold nanoparticles for glioma SPECT/CT imaging and radionuclide therapy. J. Nanobiotechnol. 2019, 17, 30. [CrossRef]

128. Xing, Y.; Zhu, J.; Zhao, L.; Xiong, Z.; Li, Y.; Wu, S.; Chand, G.; Shi, X.; Zhao, J. SPECT/CT imaging of chemotherapy-induced tumor apoptosis using. Drug Deliv. 2018, 25, 1384-1393. [CrossRef]

129. Ponti, J.; Colognato, R.; Franchini, F.; Gioria, S.; Simonelli, F.; Abbas, K.; Uboldi, C.; James Kirkpatrick, C.; Holzwarth, U.; Rossi, F. A quantitative in vitro approach to study the intracellular fate of gold nanoparticles: From synthesis to cytotoxicity. Nanotoxicology 2009, 3, 296-306. [CrossRef]

130. Pretze, M.; Hien, A.; Rädle, M.; Schirrmacher, R.; Wängler, C.; Wängler, B. Gastrin-Releasing Peptide Receptorand Prostate-Specific Membrane Antigen-Specific Ultrasmall Gold Nanoparticles for Characterization and Diagnosis of Prostate Carcinoma via Fluorescence Imaging. Bioconjug Chem. 2018, 29, 1525-1533. [CrossRef]

131. Zhang, L.; Su, H.; Wang, H.; Li, Q.; Li, X.; Zhou, C.; Xu, J.; Chai, Y.; Liang, X.; Xiong, L.; et al. Tumor Chemo-Radiotherapy with Rod-Shaped and Spherical Gold Nano Probes: Shape and Active Targeting Both Matter. Theranostics 2019, 9, 1893-1908. [CrossRef] [PubMed]

132. Freitas de Freitas, L.; Varca, G.H.C.; Dos Santos Batista, J.G.; Benévolo Lugão, A. An Overview of the Synthesis of Gold Nanoparticles Using Radiation Technologies. Nanomaterials 2018, 8, 939. [CrossRef] [PubMed]

133. Wiesing, U. Theranostics: Is it really a revolution? Evaluating a new term in medicine. Med. Health Care Philos. 2019, 11, 1-5. [CrossRef] [PubMed] 
134. Ng, Q.K.; Olariu, C.I.; Yaffee, M.; Taelman, V.F.; Marincek, N.; Krause, T.; Meier, L.; Walter, M.A. Indium-111 labeled gold nanoparticles for in-vivo molecular targeting. Biomaterials 2014, 35, 7050-7057. [CrossRef] [PubMed]

135. Kao, H.W.; Lin, Y.Y.; Chen, C.C.; Chi, K.H.; Tien, D.C.; Hsia, C.C.; Lin, M.H.; Wang, H.E. Evaluation of EGFR-targeted radioimmuno-gold-nanoparticles as a theranostic agent in a tumor animal model. Bioorg. Med. Chem. Lett. 2013, 23, 3180-3185. [CrossRef] [PubMed]

136. Shukla, R.; Chanda, N.; Zambre, A.; Upendran, A.; Katti, K.; Kulkarni, R.R.; Nune, S.K.; Casteel, S.W.; Smith, C.J.; Vimal, J.; et al. Laminin receptor specific therapeutic gold nanoparticles (198AuNP-EGCg) show efficacy in treating prostate cancer. Proc. Natl. Acad. Sci. USA 2012, 109, 12426-12431. [CrossRef]

137. Black, K.C.; Akers, W.J.; Sudlow, G.; Xu, B.; Laforest, R.; Achilefu, S. Dual-radiolabeled nanoparticle SPECT probes for bioimaging. Nanoscale 2015, 7, 440-444. [CrossRef] [PubMed]

138. Dechantsreiter, M.A.; Planker, E.; Mathä, B.; Lohof, E.; Hölzemann, G.; Jonczyk, A.; Goodman, S.L.; Kessler, H. N-Methylated cyclic RGD peptides as highly active and selective alpha(V)beta(3) integrin antagonists. J. Med. Chem. 1999, 42, 3033-3040. [CrossRef]

139. Tsoukalas, C.; Laurent, G.; Jiménez Sánchez, G.; Tsotakos, T.; Bazzi, R.; Stellas, D.; Anagnostopoulos, C.; Moulopoulos, L.; Koutoulidis, V.; Paravatou-Petsotas, M.; et al. Initial in vitro and in vivo assessment of Au@DTDTPA-RGD nanoparticles for Gd-MRI and 68Ga-PET dual modality imaging. EJNMMI Phys. 2015, 2 (Suppl. 1), A89. [CrossRef]

(C) 2019 by the authors. Licensee MDPI, Basel, Switzerland. This article is an open access article distributed under the terms and conditions of the Creative Commons Attribution (CC BY) license (http://creativecommons.org/licenses/by/4.0/). 